\title{
New Design Chart for CFRP Strengthened RC Walls with Opening in One- Way Action
}

\author{
Mehdi Lima $^{1}$, Jeung-Hwan Doh ${ }^{*}$ and Sam Fragomeni ${ }^{2}$ \\ ${ }^{1}$ School of Engineering and Built Environment, Griffith University Gold Coast Campus, \\ Queensland 4222, Australia \\ ${ }^{2}$ Victoria University, Cnr Hoadley Ct \& Ballarat Rd, Melbourne, VIC 8001, Australia \\ *Correspondence; Email: j.doh@griffith.edu.au, Tel: +61-7-5552 9141
}

\begin{abstract}
Reinforced Concrete (RC) walls have been widely used in the construction of medium/ highrise buildings due to their substantial advantages, including fast construction and costeffectiveness. Nowadays, custom architectural designs have given rise to openings in RC walls for various purposes including doors, windows and vents. Creating such openings within the existing walls alters the ultimate strength of the wall and introduces changes to the intended load path through the element. The situation will become more complex when considering the various support conditions and possible opening configurations. In this research, a comprehensive numerical investigation is completed on Carbon Fibre Reinforced Polymer (CFRP) strengthened RC walls. For the first time, a design chart is proposed for the axial load design of CFRP strengthened RC walls considering two main factors, opening configurations and CFRP layouts. The proposed charts have been verified and validated against existing experimental data and available axial load design formulae. It was found that the proposed design chart can reasonably predict the axial ultimate load capacity of CFRP strengthened RC walls. Step by step instructions are presented to employ these charts and case studies are also provided for clarification and illustration.
\end{abstract}


KEYWORDS: CFRP; RC Wall; FEM; Axial Loading; Design Code; Design Chart;

Strengthening.

\section{INTRODUCTION}

Strengthening/retrofitting of Reinforced Concrete $(\mathrm{RC})$ structures is often required due to excessive loading or change in loading, lack of required maintenance, and deterioration caused by environmental effects. Eccentric loading conditions can occur within RC walls due to corbel elements attached to the wall, uneven loading conditions on top of the wall, imperfections in construction, or temporary loading during/after construction. Carbon Fibre Reinforced Polymer (CFRP) is a favourable option used for the strengthening of $\mathrm{RC}$ elements due to its high tensile strength and lightweight. Extensive experimental and numerical studies have been carried out on CFRP strengthening/retrofitting of the different types RC structural members including columns, beams, slabs and shear walls, where a review paper has been published on this topic [1]. Several national codes and standards have been published for FRP applications in RC members [2-6]. However, these guidelines do not provide a procedure for the design of CFRP strengthened RC walls under eccentric axial loads. In RC walls under eccentric axial load, the presence of an opening results in local cracking in the vicinity of the opening resulting in an obvious reduction in load-carrying capacity. The CFRP layout can be utilised in order to improve the performance of the wall in this situation. Significant research has been carried out on the behaviour of $\mathrm{RC}$ walls with various material properties, geometry and support conditions [7-13], without FRP strengthening where guidelines have been provided to design such RC walls [14-15].

Load-bearing walls restrained on top and bottom only, with free vertical edges, behave in one-way action (see Fig. 1 (a)). Axially loaded walls can also behave in two-way action when restrained on four sides (see Fig. 1(b)). The typical crack patterns and curvature scenarios for a wall with a single opening behaving in one-way action (OW) and two-way (TW) action are also depicted in Fig. 1. 


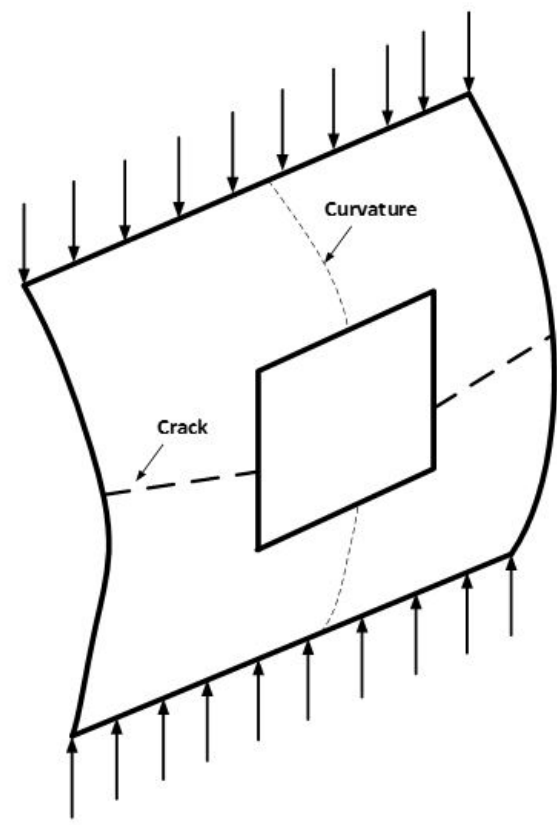

(a)

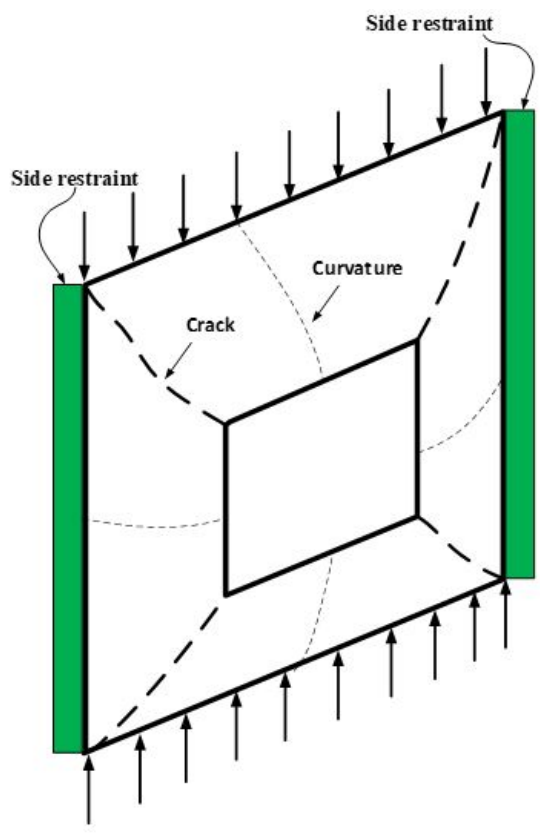

(b)

FIGURE 1 Walls with and without side supports (a) OW, (b) TW4S

The Australian Standard AS3600 [15] provides simplified guidelines for the design of reinforced concrete walls subjected to vertical compression forces acting in one-way and twoway action. However, the American Concrete Institute Code ACI-318 [14] only provides a procedure for the simplified design of vertically loaded concrete walls acting in one-way action. AS3600 [15] provides general guidelines only for two-way walls with openings where the effect of opening can be ignored if the total area of openings is less than $1 / 10$ of the area of the wall, and the height of an opening is less than $1 / 3$ of the height of the wall. In this case of two-way action, the simplified design equation can be used, ignoring any opening(s) [15]. (Note the design of walls for in-plane shear forces is treated separately in AS and ACI and is not within the scope of this paper).

Considering the extensive research completed on the behaviour of RC walls without FRP strengthening, limited studies have been conducted on the behaviour of CFRP strengthened RC walls. There is a need to understand how CFRP enhances ultimate strength and what the optimum orientation is. 
Mohammed et al. [16] proposed design equations (given Eq. 1) based on experimental tests of eight RC walls under one-way action with two different CFRP layouts. Various opening sizes $(5,10,20,30$ percent of the wall area) were considered at the centre of the RC wall. For all the wall series; aspect ratios $\left(\mathrm{H}_{\mathrm{w}} / \mathrm{L}_{\mathrm{w}}\right)$, slenderness ratios $\left(\mathrm{H}_{\mathrm{w}} / \mathrm{t}_{\mathrm{w}}\right)$ and thinness ratios $\left(\mathrm{L}_{\mathrm{w}} / \mathrm{t}_{\mathrm{w}}\right)$ were 2 , 20 and 10, respectively. Further information about this experimental program can be found in the original article. The test outcomes indicated that the EB (Externally Bonded) CFRP applications on the tension face of RC walls supported on top and bottom only (one-way action) would increase the ultimate strength of the walls between $8 \%$ and $90 \%$, depending on the opening size and CFRP arrangement. Mohammed et al. [16] reported that applying CFRP layout at $45^{0}$ to the opening corners resulted in a higher contribution to ultimate strength in comparison to cases where CFRP was applied all around the opening. The equation for ultimate capacity is therefore given as:

$$
\begin{array}{ll}
N_{A F}=(2.0765-2.1186 \chi) N_{N F} & \text { Eq. 1 (a) } \\
N_{D F}=(2.4708-2.6099 \chi) N_{N F} & \text { Eq. 1 (b) }
\end{array}
$$

where $N_{N F}$ is the ultimate load of the RC wall without CFRP; $N_{A F}$ and $N_{D F}$ are representing the ultimate load of CFRP strengthened RC walls with AF and DF layouts, respectively (given in Fig. 2). The parameter $\chi=A o / A+\eta / L_{w} ; \eta=\left(L_{w} / 2\right)-\bar{\eta} ; \bar{\eta}=\left(L^{2}{ }_{w} t_{w} / 2-L_{o} t_{w} \eta_{o}\right) /\left(L_{w} t_{w}-L_{o} t_{w}\right)$ and $N_{u}$ is the ultimate failure load of solid walls; $\mathrm{L}_{\mathrm{o}}$ and $\mathrm{H}_{\mathrm{o}}$ are the dimensions of the opening in $\mathrm{mm}$; $\mathrm{A}_{\mathrm{o}}=\mathrm{L}_{\mathrm{o}} \mathrm{t}_{\mathrm{w}} ; \mathrm{A}_{\mathrm{g}}=\mathrm{L}_{\mathrm{w}} \mathrm{t}_{\mathrm{w}} ; \eta$ is the distance between the centres of gravity of an RC wall section in plane with and without openings in $\mathrm{mm} ; \eta_{\mathrm{o}}$ and $\bar{\eta}$ are distances of the centres of gravity of the opening and of a wall without an opening from the left edge of the wall, respectively in $\mathrm{mm}$ as shown in Fig. 3. 


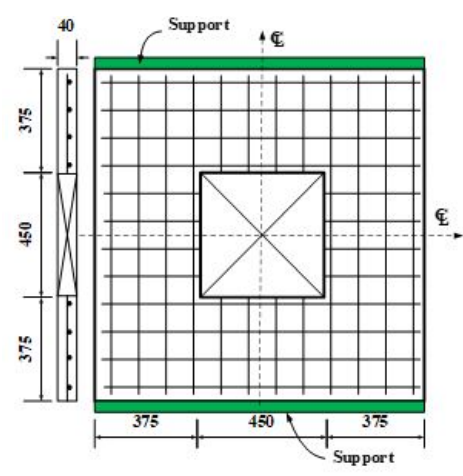

(a)

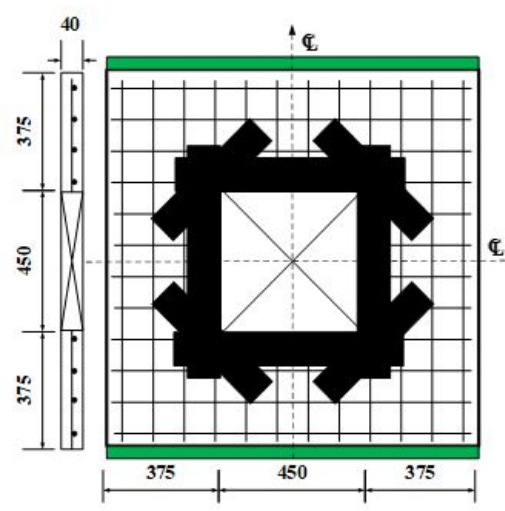

(d)

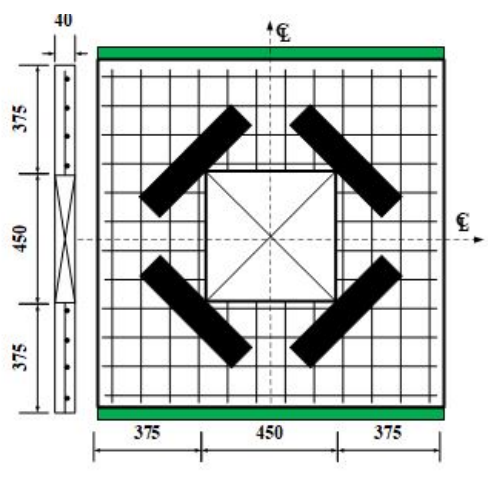

(b)

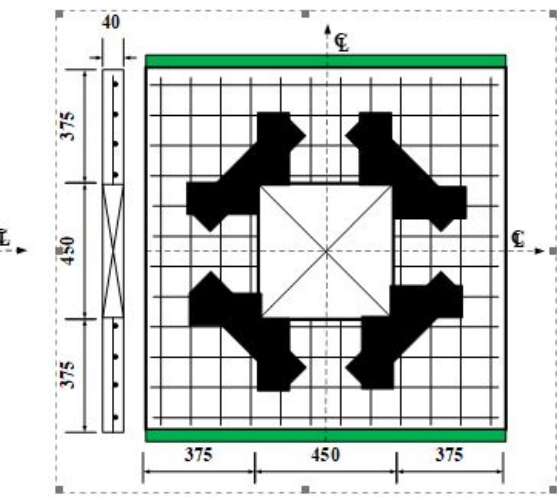

(e)

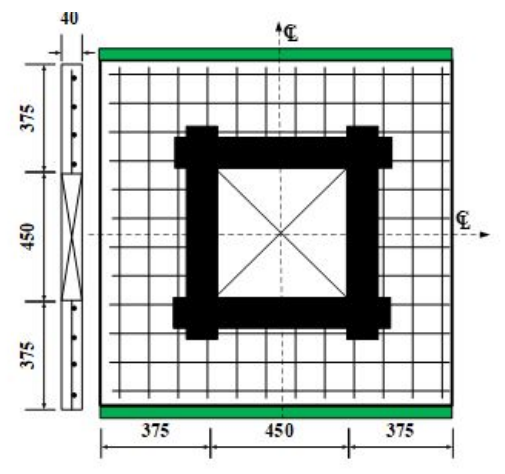

(c)

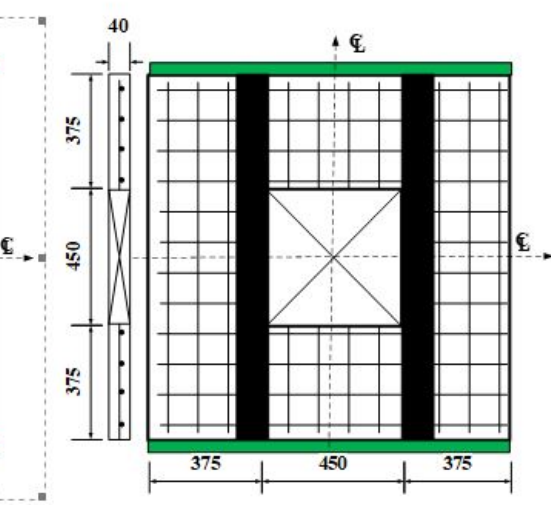

(f)

FIGURE 2 Panel designation and CFRP layout for walls (dimensions in mm) [17]. (a)OW$\mathrm{NF}$, (b) OW-DF, (c) OW-AF, (d) OW-CF, (e) OW-WF, (f) OW-PF

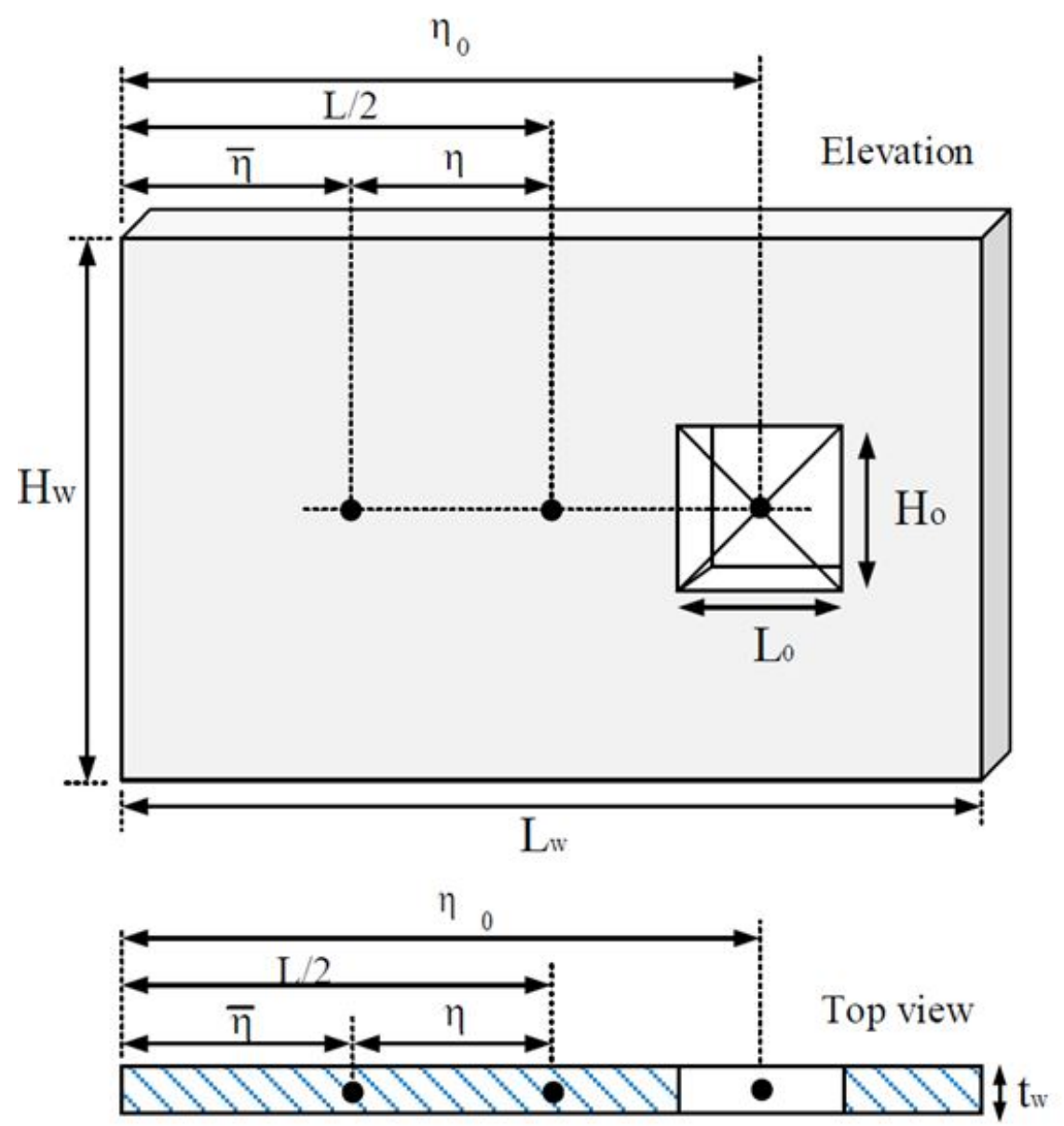

FIGURE 3 Geometric parameters for the wall with openings [18] 
Lima et al. [1] completed a Fintie Element analysis on CFRP strengthened RC walls with an opening in one-way action. It was evident that the CFRP has a greater contribution to the ultimate strength of the wall when the opening size increases and more CFRP is applied. The investigation also revealed that for a wall with one-way action, the application of CFRP layout at $45^{0}$ to the opening corners resulted in a lower enhancement in ultimate strength in comparison to the case of the wall with CFRP applied all around (0/90 degree) the opening.

Popescu et al.[19] completed an experimental investigation on FRP-strengthened RC walls with door openings restrained on four sides. A mechanical anchorage system was used to anchor the wrapped FRP around the opening. Pre-cracking was introduced in some models with loading up to $75 \%$ of the wall's capacity and some samples were uncracked. The combination of FRP wrapping and using the mechanical anchorages increased the axial capacity of walls with small (25\%) and large (50\%) openings by $34 \%-50 \%$ and $13 \%-27 \%$, respectively. In comparison to the capacity of the corresponding solid wall, this enhancement in ultimate load was equal to $94.8 \%$ and $63.4 \%$, respectively. During the experimentation, concrete crushing of wall and debonding of FRP sheet was recorded at ultimate load.

Popescu et al. [20] proposed a formula to estimate the ultimate load of fully wrapped CFRP walls under axial (in-plane) loading. The proposed formula is applicable for walls with two-way action supported on all four sides. A concrete model with an enhanced compressive strength was utilized to consider the contribution of the wrapped CFRP in the ultimate load of the piers. They claimed that the formula has an average accuracy of $95 \%$ with a coefficient of variation of $14.6 \%$.

The recent research conducted by Lima et al. [17] demonstrated that the CFRP has a greater contribution to the ultimate strength of the wall when the opening size increases and more CFRP is applied. The investigation also revealed that for the wall in one-way action, the application of CFRP layout at $45^{\circ}$ to the opening corners resulted in a lower enhancement in ultimate strength in comparison to the case of the wall with CFRP applied all around $\left(0^{0} / 90^{0}\right)$ the opening.

Considering the current investigation on the behaviour of RC walls [1,16-17], the existing design formulae for CFRP strengthened walls in one-way action and two-way action are not applicable for various CFRP layouts or limited to specimens with fully wrapped CFRP. 
Furthermore, discrepancies exist in findings for $\mathrm{RC}$ walls in $\mathrm{OW}$ action particularly with, diagonal placement to the opening's corner $\left(45^{0}\right)$ compared to parallel placement to the opening's edges $\left(0^{0} / 90^{0}\right)$.

Hence, this research aims to investigate the contribution of various CFRP layout configurations to the ultimate strength of the $\mathrm{RC}$ walls, and opening configuration culminating in the introduction of the design chart for engineering application. Neither horizontal in-plane nor lateral forces were applied during the simulation as only the axial load capacities of CFRP strengthened concrete walls with the opening were of interest in this study.

The investigation was undertaken using the following stages: a) a comparative study with the existing experimental data to establish a reliable FE model; b) a comprehensive numerical investigation considering various opening configurations (size and location) and CFRP layouts; c) design chart is proposed for CFRP strengthened vertically loaded RC walls based on obtained results from numerical investigation; d) a guided step-by-step procedure provided for engineers using for design chart, and e) a case study presented for clarification and illustration purposes in using the design chart.

\section{WALL SPECIMENS}

Six (6) experimental test results by Lima et al. [17] were selected for this study from which a reliable model for parametric investigation could be established. A detailed description of the experimental program is given by Lima et al. [17]. The nominal width, length and thickness of the selected wall specimens were $1200 \mathrm{~mm}, 1200 \mathrm{~mm}$ and $40 \mathrm{~mm}$, respectively. A single layer of reinforcement mesh of $6 \mathrm{~mm}$ diameter with a spacing of $100 \mathrm{~mm}$ was placed at the middle of the wall section. Five CFRP sheet layouts and one without CFRP (control sample) walls were modelled considering an identical opening size (as shown in Fig. 2). The width of the CFRP layer was $105 \mathrm{~mm}$ and the length varied for different patterns. The walls were subjected to a vertical load on top of the wall with an eccentricity of $t_{w} / 6$ and the ultimate load, deflections 
as well as crack patterns were recorded and presented in the original paper [17].

Details of the CFRP layout, including the opening configuration of the walls, is presented in Fig. 2. The walls have been designated as follows: 1) OW- one-way buckling supported top and bottom only and the last two letters denote the CFRP layouts. The nomenclature for seven distinguished CFRP layouts were designated as follows: NF- no CFRP (Control wall); AF using CFRP alongside the opening; DF using CFRP diagonal to the opening; CF using CFRP as combination of AF and DF; WF using CFRP wrapped around the opening and PF using CFRP parallel to the opening.

\section{NUMERICAL FINITE ELEMENT MODELLING (FEM)}

The numerical simulation is a useful tool to investigate various structural elements due to more flexibility in modifying the model as well as being cost and time-saving in comparison to extensive experimental testing. Several literature reviews and numerical investigation have been completed on RC components [1, 21-24]. Among the available tools for numerical investigation, Abaqus is a commercial software package that has been used for various FEM investigations and was available at the time of this research to be utilised as a tool for modelling. The reinforcement bar was defined as an elastic-perfect plastic material using a truss element. The elastic modulus, yield stress and Poisson's ratio of reinforcement were $210 \mathrm{GPa}, 500 \mathrm{MPa}$ and 0.3 respectively. The concrete behaviour in compression was simulated using the proposed formula by Hsu \& Hsu [25] and for concrete under uniaxial tension $f_{t}^{\prime}$ and $G_{f}$ were estimated from the CEB-FIP [26]. The bond-slip between concrete and steel is not considered, and the steel reinforcement was simulated as truss elements embedded in a concrete region in which the concrete and the reinforcement share the same node where a perfect bond is assumed.

The Poisson's ratio of concrete was assumed as 0.2 [15]. The compressive strength used for each panel is presented in Table 2. The CFRP layout was assumed as an orthotropic material where the modulus of elasticity was considered as $\mathrm{E}_{11}=234 \mathrm{GPa}, \mathrm{E}_{22}=\mathrm{E}_{33}=4.5 \mathrm{GPa}$ in various 
directions of the layout. The Poisson's ratio was designated as $0.3,0.3,0.45$ for $v_{12}, v_{13}$ and $v_{23}$, respectively. The material properties of CFRP in the model was considered as follows: $\mathrm{G}_{12}=2.77 \mathrm{GPa}$ and $\mathrm{G}_{13}=\mathrm{G}_{23}=1.5 \mathrm{GPa}$ were used as the shear modulus of the CFRP layer in various directions. The 8-node brick elements (three degrees of freedom per node), were used to model the concrete, CFRP and restraints. An appropriate contact was also considered between the restraints and concrete elements. The plastic damage parameters of concrete were assumed as follows: dilation angle: $12^{0}$; the flow potential eccentricity: 0.1 , the ratio of initial equibiaxial compressive yield stress to initial uniaxial compressive yield stress: 1.16 , the ratio of the second stress invariant on the tensile meridian to that on the compressive meridian: 0.667 and the viscosity parameter: $10^{-5}$. In this study, the Riks method [27] was used for the analysis of all numerical models.

A cohesive contact was utilised to simulate the CFRP-concrete interface. In Fig. 4, a schematic of a simple bilinear traction-separation law [27] was presented based on the effective traction, $\tau_{\max }$ and effective opening displacement, $\delta$.

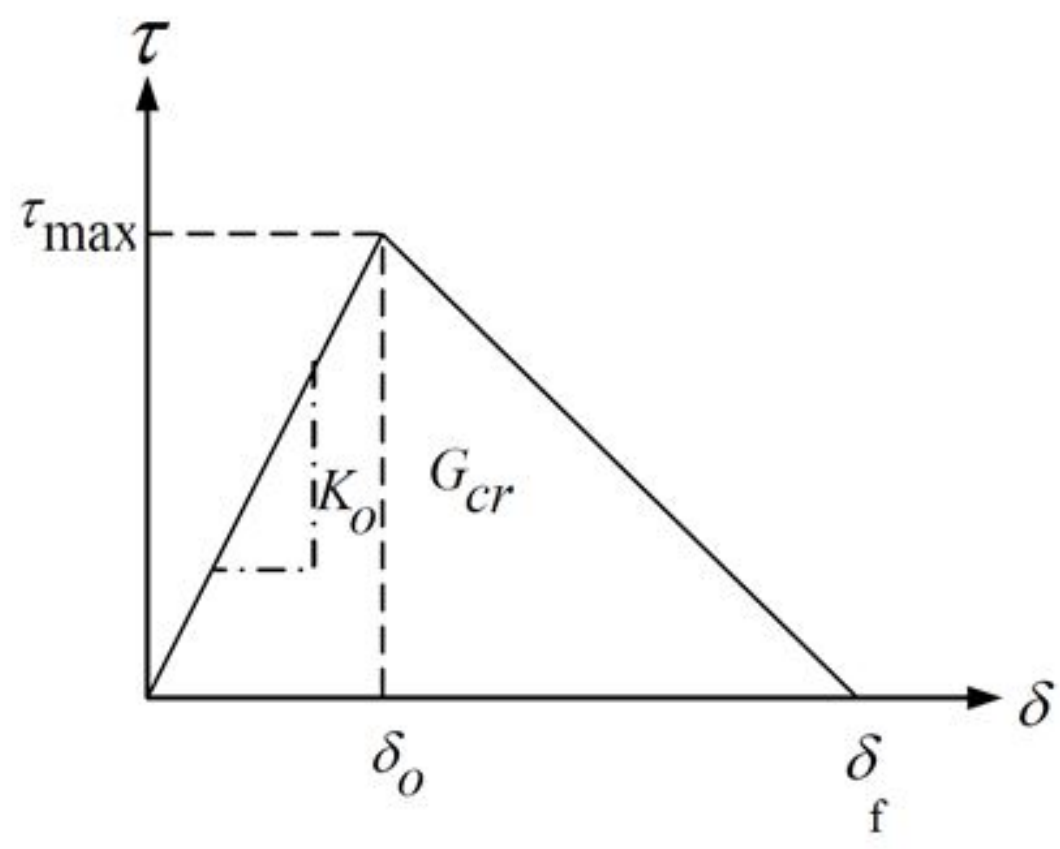

FIGURE 2 The schematic shape of bilinear traction-separation constitutive law [27] 
The initial stiffness of the interface was defined based on the proposed method by Guo et al.[28] as follows:

$$
\mathrm{K}_{0}=\frac{1}{\frac{\mathrm{t}_{\mathrm{i}}}{\mathrm{G}_{\mathrm{i}}}+\frac{\mathrm{t}_{\mathrm{c}}}{\mathrm{G}_{\mathrm{c}}}}
$$

where $t_{i}$ and $t_{c}$ were the resin and concrete thickness, respectively. $G_{i}$ and $G_{c}$ were the shear modulus of resin and concrete, respectively. An upper limit for the maximum shear stress ( $\tau_{\max }$ ) was calculated based on Eq. 3 proposed by Lu et al. [29].

$$
\tau_{\max }=1.5 \beta_{w} \mathrm{f}_{\mathrm{t}}
$$

where $\beta_{w}=\sqrt{2.25-\left(\mathrm{b}_{\mathrm{f}} / \mathrm{b}_{\mathrm{c}}\right)} / \sqrt{1.25+\left(\mathrm{b}_{\mathrm{f}} / \mathrm{b}_{\mathrm{c}}\right)}$ in which, $\mathrm{b}_{\mathrm{f}}$ and $\mathrm{b}_{\mathrm{c}}$ are the CFRP and concrete width and $f_{t}$ is the concrete tensile strength. Damage initiation was based on a quadratic traction function involving the nominal stress ratios. The initiation of damage occurs when the submission of these values reached the one as denoted by Hibbitt et al. [27]:

$$
\left\{\frac{\sigma_{\mathrm{n}}}{\sigma_{\mathrm{n}}^{\mathrm{o}}}\right\}^{2}+\left\{\frac{\tau_{\mathrm{s}}}{\tau_{\mathrm{s}}^{\mathrm{o}}}\right\}^{2}+\left\{\frac{\tau_{\mathrm{t}}}{\tau_{\mathrm{t}}^{\mathrm{o}}}\right\}^{2}=1
$$

where $\sigma_{\mathrm{n}}$ is the cohesive tensile stress and, $\tau_{\mathrm{s}}$ and $\tau_{\mathrm{t}}$ are shear stresses of the interface, and $\mathrm{n}$, $\mathrm{s}$, and $\mathrm{t}$ refer to the direction of the stress component.

The energy release concept was employed to define the interface damage evolution. Benzeggah-Kenane fracture criterion [27] was applied to specify the dependence of the fracture energy on the mode mix, shown as follows:

$$
G_{n}^{c}+\left(G_{s}^{c}-G_{n}^{c}\right)\left(\frac{G_{\phi}}{G_{\xi}}\right)=G^{C}
$$


where $G_{\phi}=G_{s}+G_{t}, G_{\xi}=G_{s}+G_{n}$ and $G_{n}, G_{s}$ and $G_{t}$ refer to the critical fracture energies required to cause failure in the normal, the first and the second direction, respectively.

Mesh convergence sensitivity was performed for all specimens in order to achieve minimum discrepancy in the element behaviour and failure load. Also, the aim was to have a square element for all specimens. Herein, the mesh sensitivity study is presented considered three configurations that included coarse, medium and fine meshes (Fig. 5). In order to investigate the mesh sensitivity in the RC wall panels, the mesh sizes for other parts, such as reinforcement bars and supports were maintained. Using a coarse mesh resulted in lower peak loads and deflection compared to the experimental outcomes. The peak loads predicted for the varied mesh densities are provided in Table 1. The outcomes for ultimate loads and deflection by using fine and medium mesh were similar; however, the fine mesh generation was deployed to accurately consider the eccentric load application.

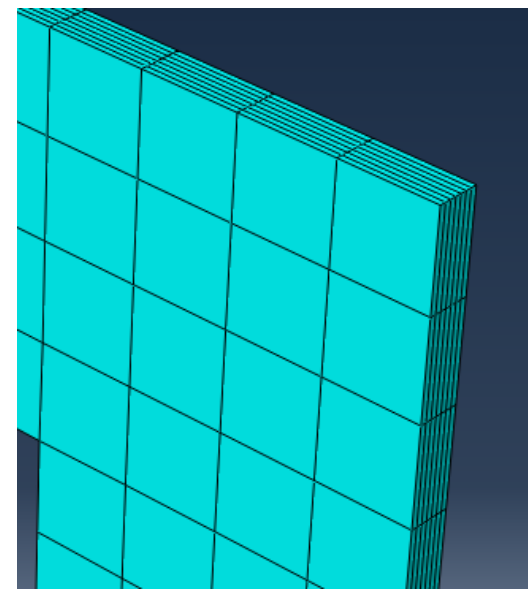

(a) Coarse

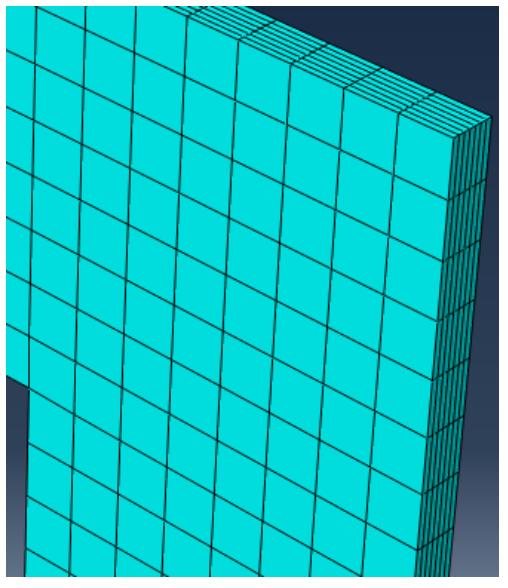

(b) Medium

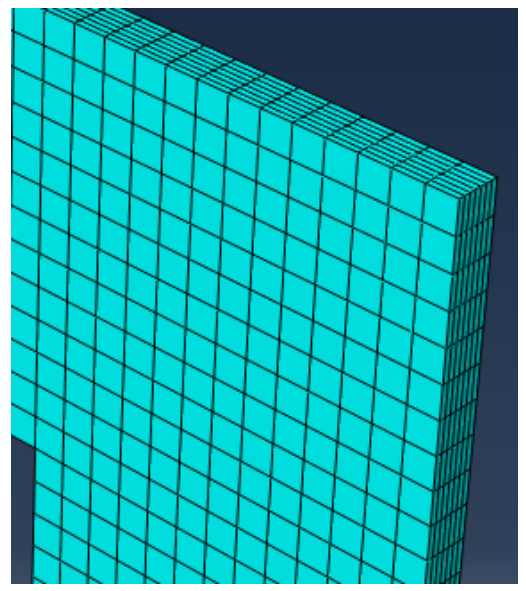

(c) Fine

Figure 5 Mesh sensitivity study for RC walls (general seed) 
TABLE 1 Mesh configurations used during the convergence study of the RC walls

\begin{tabular}{|c|c|c|c|c|c|c|}
\hline \multirow{2}{*}{ Mesh } & \multirow{2}{*}{$\begin{array}{l}\text { Number of } \\
\text { layers in } \\
\text { thickness }\end{array}$} & \multirow{2}{*}{$\begin{array}{c}\text { Size of } \\
\text { the mesh } \\
\text { seed }\end{array}$} & \multirow{2}{*}{$\begin{array}{l}\text { Number of } \\
\text { elements }\end{array}$} & \multicolumn{2}{|c|}{ Ultimate load $(\mathrm{kN})$} & \multirow{2}{*}{$\frac{\text { Num }}{\operatorname{Exp}}$} \\
\hline & & & & $\mathrm{Num}^{1}$ & $\operatorname{Exp}^{2}$ & \\
\hline \multirow{3}{*}{ Coarse } & 5 & 100 & 8068 & 252.58 & \multirow{7}{*}{266.00} & 0.95 \\
\hline & 7 & 100 & 8356 & 268.80 & & 1.01 \\
\hline & 10 & 100 & 8788 & 271.44 & & 1.02 \\
\hline \multirow{2}{*}{ Medium } & 5 & 50 & 10068 & 242.40 & & 0.91 \\
\hline & 7 & 50 & 11156 & 244.80 & & 0.92 \\
\hline \multirow{2}{*}{ Fine } & 5 & 30 & 14628 & 243.60 & & 0.92 \\
\hline & 7 & 30 & 17540 & 249.15 & & 0.94 \\
\hline
\end{tabular}

${ }^{1}$ Num: Numerical, ${ }^{2}$ Exp: Experimental [18]

\section{COMPARATIVE STUDY}

\subsection{Crack patterns}

In Fig. 6, the $\mathrm{RC}$ wall crack patterns resulting from the $\mathrm{FE}$ analysis are compared with the experimental test results [17]. By utilsing the Maximum Principle Plastic Strain (PE) in the numerical modelling, which in the model is defined as cracking strain, it was possible to determine the area(s) experiencing cracks or fractures. 


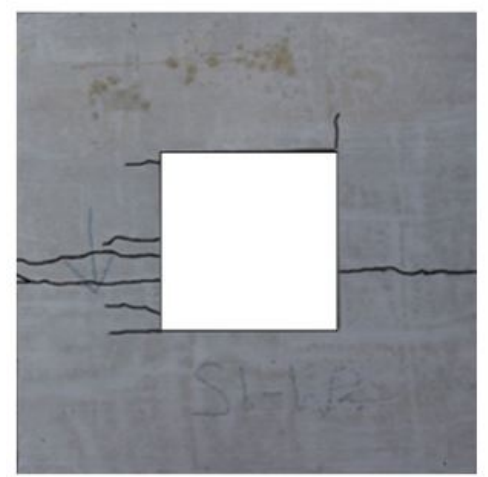

(a)

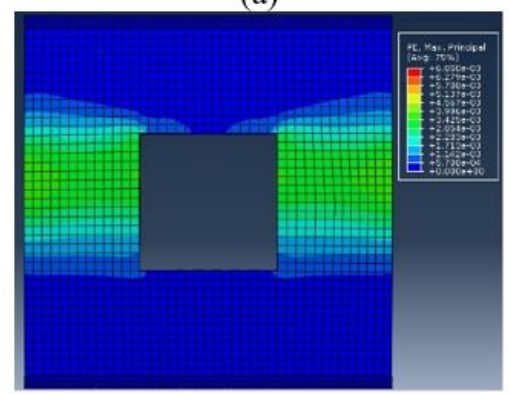

(b)

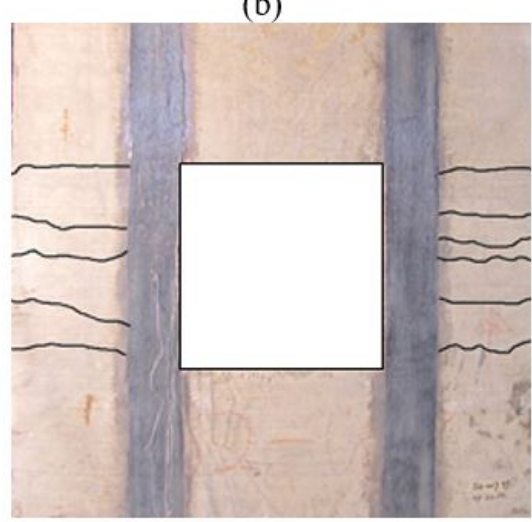

(g)

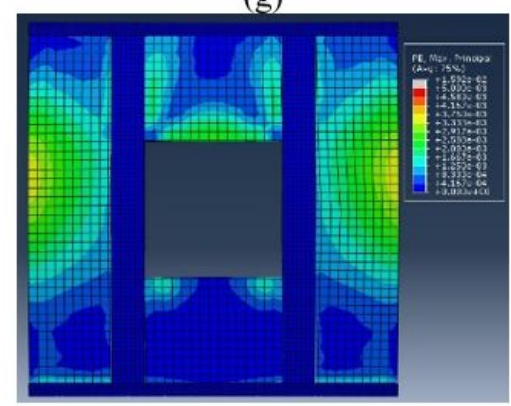

(j)

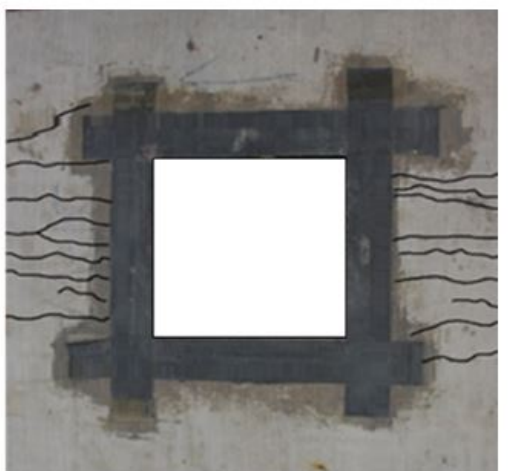

(c)

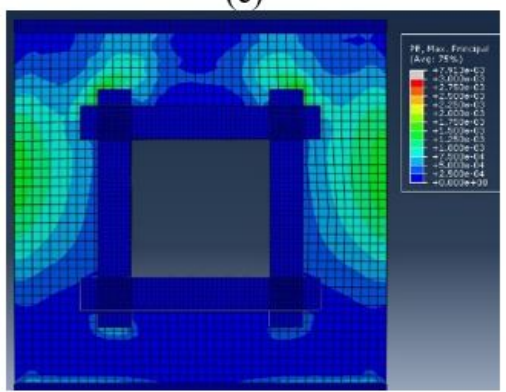

(d)

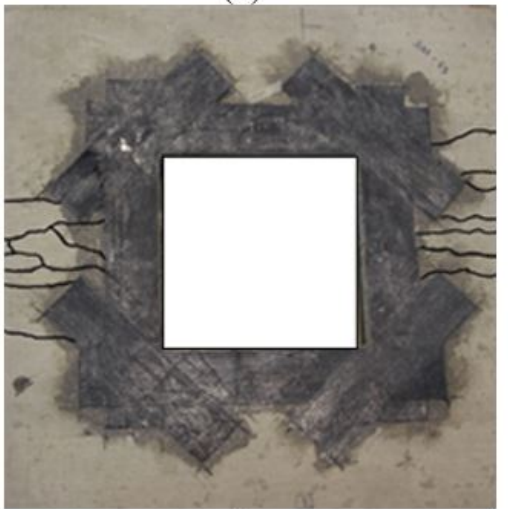

(h)

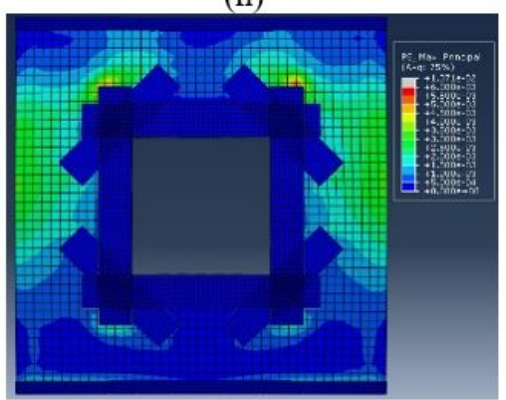

(k)

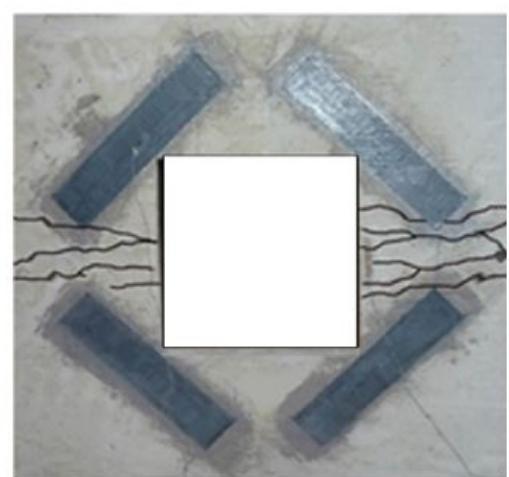

(e)

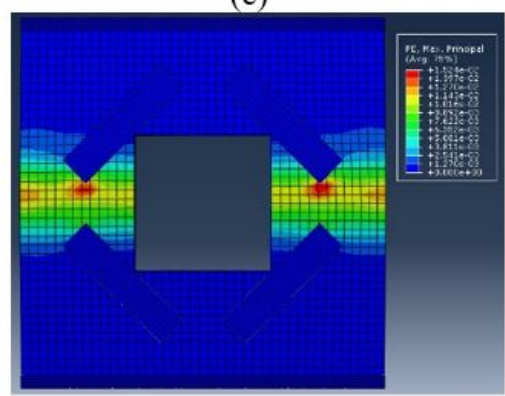

(f)

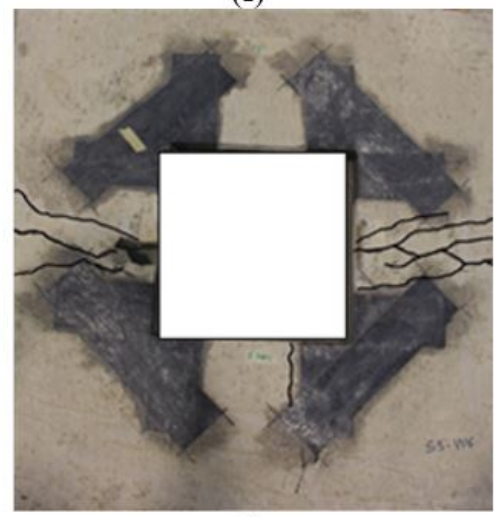

(i)

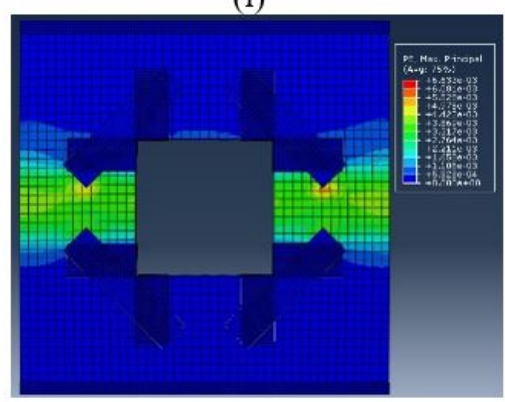

(1)

FIGURE 6 Crack pattern comparison between experiments [17] and numerical analysis. (a) OW-NF (Exp), (b) OW-AF (Exp), (c) OW-DF (Exp), (d) OW-NF (Num), (e) OW-AF (Num), (f) OW-DF (Num), (g) OW-PF (Exp), (h) OW-CF (Exp), (i) OW-WF (Exp), (j) OW-PF (Num), (k) OW-CF (Num), (l) OW-WF (Num)

It is evident from Fig. 6 that by providing restraints at the top and bottom only, the RC walls typically experienced horizontal cracks throughout the mid-height of the opening. The horizontal crack distribution at mid-height did not change significantly, irrespective of the 
CFRP layout used. Generally, the maximum PE was observed in the area of the wall where the CFRP was not provided.

For the panel with OW-DF, the ultimate strength of the RC wall was not considerably increased, which was expected since the weakest part of the wall (mid-height) was not strengthened. A similar crack outcome was observed for the OW-WF panel, where Maximum PE was observed in the mid-height of the panel. However, the OW-WF panel, with a U-shaped CFRP layout applied around the corner of the opening, resulted in a greater increase in ultimate strength compared to the DF layout. This was attributed to more wall area able to resist bending with the applied CFRP assisting with load distribution.

Significantly, the CFRP application alongside the opening in panels OW-AF, OW-CF and OW-PF resulted in more distributed cracks across the opening region (on the tension side). This was demonstrated by the maximum PE where the more distributed plastic strain was observed in these cases in comparison to OW-WF and OW-DF walls. Based on the type of CFRP layout, various degrees of ultimate wall strength enhancement was observed in. In the FEM simulation, no evidence of de-bonding between concrete and CFRP for all RC walls was observed which was identical to the observations of the experiments.

\subsection{Load versus Deflection}

The load versus deflection curves from FEM analysis are presented in Fig. 8 for all panels and compared with corresponding experimental results [17]. Most of the walls failed in a brittle mode and the sudden failure of these panels made it difficult to record deflection precisely at failure. Importantly the maximum deflections were obtained just prior to failure load is reached. Thus in the figures presented, the absolute maximum failure loads and the corresponding maximum deflections are not shown.

The vertical in-plane deflections were also recorded to investigate the shortening of the walls. The location of the dial gauges for defection recording is shown in Fig. 7 In the FE analysis, 
the deflection of the walls at the same location was obtained and compared with the experimental results.

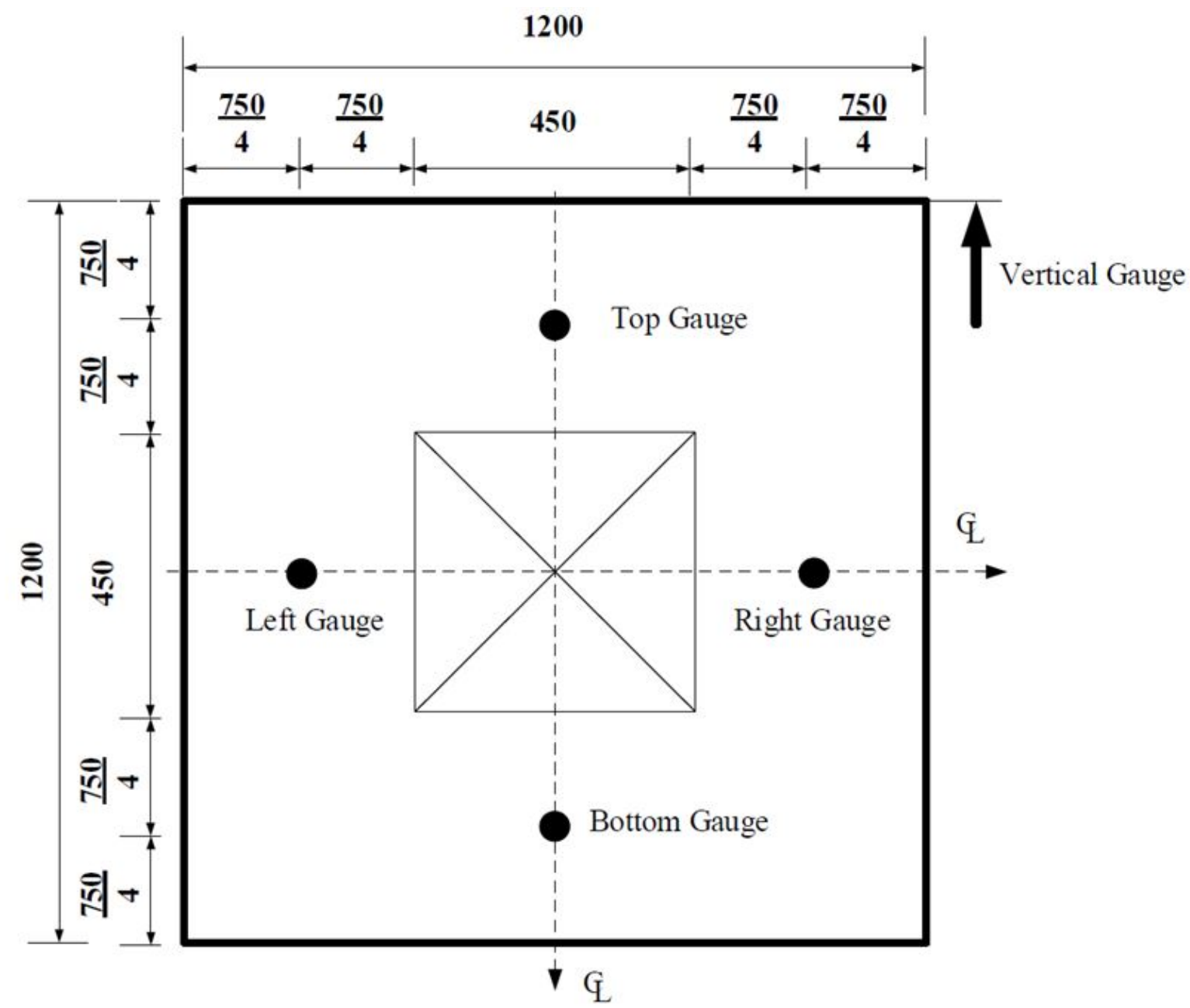

FIGURE 7 Typical dial gauge locations on wall panels in the compression side (dimensions in $\mathrm{mm}$ ) [17]

Fig. 8 indicated that the vertical deflection of the RC walls was much smaller than the maximum lateral deflection of the walls with similar outcomes observed in the experimental program. It is also evident the load-deflection profiles of the FEM analysis adequately follow the profiles of the experimentally measured results, reinforcing the accuracy of the comparative study. Finally, it can be seen that CFRP reinforced walls exhibited a larger lateral deflection in comparison to samples without CFRP or to those with CFRP applied beyond the area of the wall under bending. 


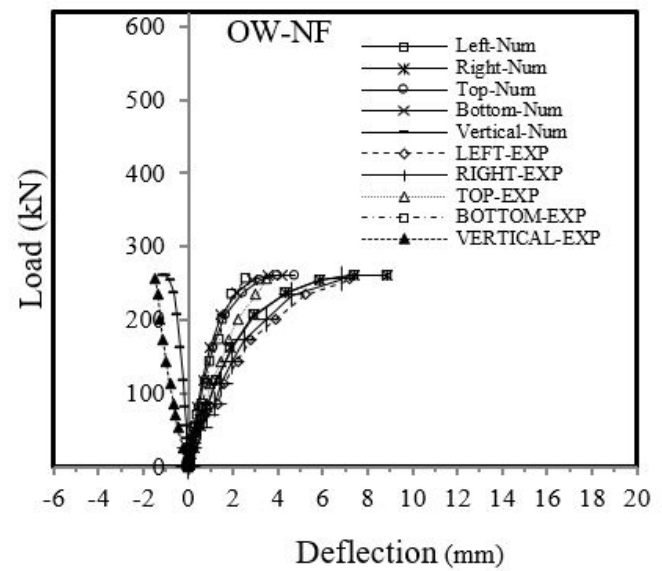

(a)

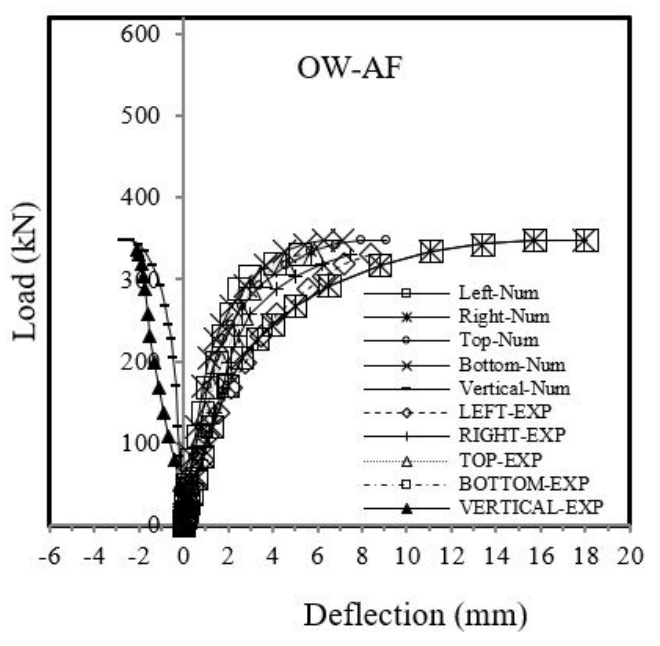

(c)

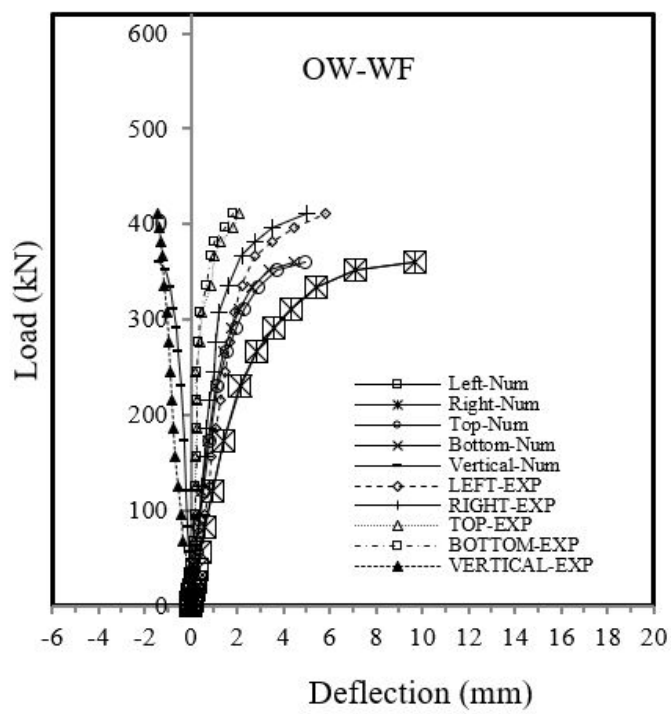

(e)

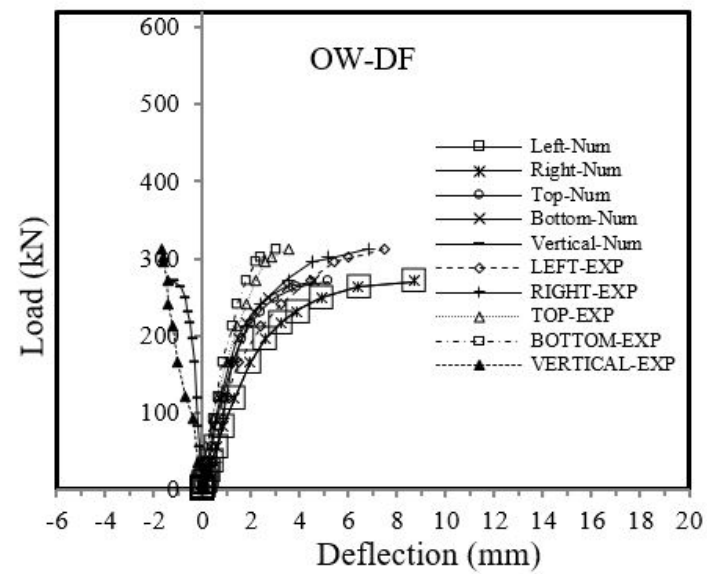

(b)

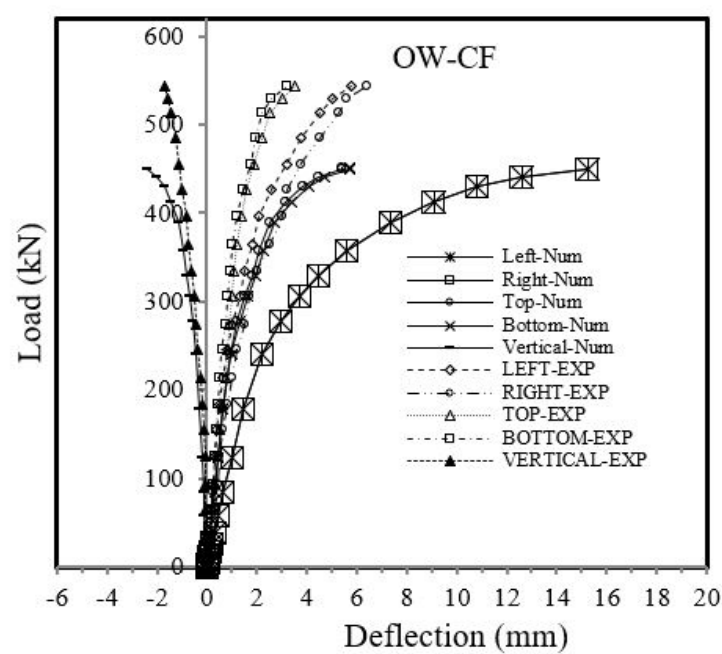

(d)

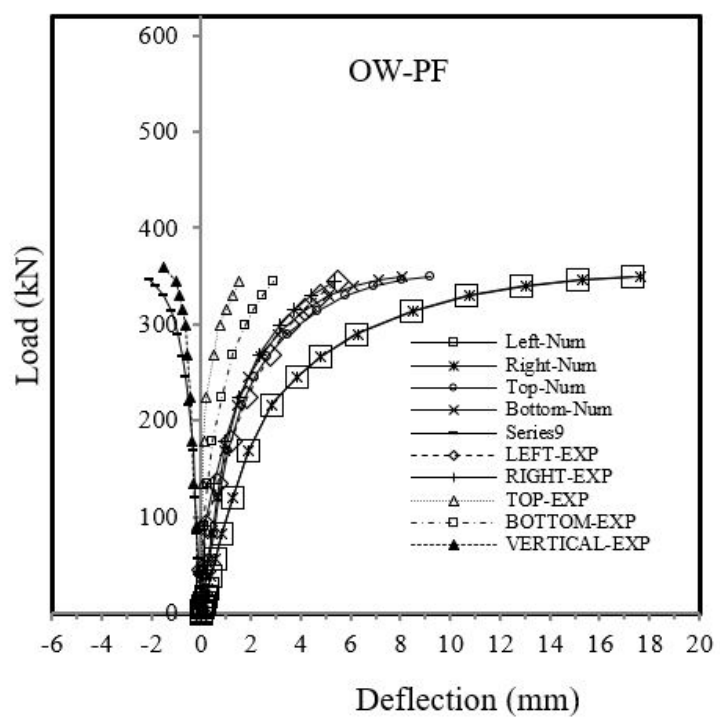

(f)

FIGURE 8 Compression of load versus lateral deflection curves obtained from experiments (Lima et al. [17] and numerical simulation for walls with OW (refer to FIGURE 7 for gauge locations) (a)

OW-NF, (b) OW-DF, (c) OW-AF, (d) OW-CF, (e) OW-WF, (f) OW-PF 


\subsection{Ultimate axial strength}

The failure loads for all the panels were recorded and are expressed as a dimensionless quantity - axial strength ratio, $\mathrm{N}_{\mathrm{NF}\left({ }^{*} \mathrm{~F}\right)} /\left(\mathrm{f}_{\mathrm{c}}^{\prime} \mathrm{L}_{\mathrm{w}} \mathrm{t}_{\mathrm{w}}\right)$, in Table 2 . During the experimental study the true thickness of walls was measured prior to testing and compressive strength of concrete was obtained ${ }^{17}$. In this table, $\mathrm{N} * \mathrm{~F}$ represents the ultimate load of CFRP strengthened RC walls with various CFRP layouts. The subscript * was replaced by D, A, C, and W for CFRP layout of $\mathrm{DF}, \mathrm{AF}, \mathrm{CF}$ and $\mathrm{WF}$, respectively. $\mathrm{N}_{\mathrm{NF}}$ was designated as the ultimate load of walls without CFRP. The numbers in the parentheses give the percentage increase in the axial strength ratios between the without CFRP (NF) wall and CFRP strengthened wall for each support condition considered.

It is evident from Table 2 that varying the CFRP layouts has a significant effect on axial wall strengths. The ultimate strengths of walls from the numerical study with DF, AF, WF, CF and PF layouts increased by $3.0 \%, 24.1 \%, 7.1 \%, 31.6 \%$ and $12.7 \%$, respectively. However, this observation contradicts the results obtained by Mohammed et al. [16]. Their study showed the DF pattern walls achieved a higher load capacity than walls with the AF layout. The test results showed the same trend as this numerical study, that the AF layout also produced a higher strength increase than DF. It is concluded here that the higher contribution of CFRP in ultimate strength for the OW-AF panel is related to the CFRP application around the opening as the weakest part of the wall was strengthened. 
TABLE 2 Ultimate axial load strength comparison between FEM and experiments

\begin{tabular}{|c|c|c|c|c|c|c|c|}
\hline \multirow{2}{*}{$\begin{array}{l}\text { Wall Designation } \\
\text { (Lima et al. [17]) }\end{array}$} & \multirow{2}{*}{$\begin{array}{c}\mathrm{f}_{\mathrm{c}} \\
(\mathrm{MPa})\end{array}$} & \multirow{2}{*}{$\begin{array}{c}\text { Wall } \\
\text { Thickness } \\
(\mathrm{mm})\end{array}$} & \multicolumn{2}{|c|}{$\begin{array}{l}\text { Ultimate Load } \\
\mathrm{N}_{\mathrm{NF}\left({ }^{*} \mathrm{~F}\right)} \\
(\mathrm{kN})\end{array}$} & \multicolumn{3}{|c|}{$\begin{array}{l}\text { Axial strength ratio } \\
\mathrm{N}_{\mathrm{NF}\left({ }^{*} \mathrm{~F}\right)} / \mathrm{f}_{\mathrm{c}} \cdot \mathrm{L}_{\mathrm{w}} \cdot \mathrm{t}_{\mathrm{w}}\end{array}$} \\
\hline & & & $\operatorname{Exp}^{1}$ & $\mathrm{Num}^{2}$ & Exp & Num & $\frac{\text { Num }}{\text { EXP }}$ \\
\hline OW-NF & 54.7 & 40.0 & 266.00 & 261.07 & 0.101 & 0.099 & 0.98 \\
\hline OW-DF & 55.0 & 40.0 & 309.00 & 270.36 & $0.117(15.5 \%)$ & $0.102(3.0 \%)$ & 0.87 \\
\hline OW-AF & 54.7 & 40.0 & 335.70 & 324.00 & $0.128(26.2 \%)$ & $0.132(24.1 \%)$ & 0.97 \\
\hline OW-WF & 62.6 & 43.5 & 415.05 & 348.00 & $0.127(25.4 \%)$ & $0.106(7.1 \%)$ & 0.84 \\
\hline $\mathrm{OW}-\mathrm{CF}$ & 62.6 & 46.0 & 559.00 & 452.00 & $0.162(59.7 \%)$ & $0.131(31.6 \%)$ & 0.81 \\
\hline OW-PF & 64.9 & 40.0 & 359.85 & 349.20 & $0.1165(14.0 \%)$ & $0.124(12.7 \%)$ & 0.97 \\
\hline${ }^{1}$ Exp: Experime & & & & & & $\begin{array}{l}\text { Mean } \\
\text { STDV }\end{array}$ & $\begin{array}{c}0.91 \\
0.076 \\
\end{array}$ \\
\hline
\end{tabular}

Considering the outcomes from both the numerical and experimental investigation, it was evident that the axial strength ratio of the walls with CF layout resulted in the largest increased load capacity for the RC walls considered. It should also be emphasised here that when considering the comparative experimental and numerical results, it can be concluded that the FEM was able to estimate the experimental behaviour of CFRP strengthened panels with a mean accuracy of 0.91 and a standard deviation of $\pm 7.6 \%$ which is within an acceptable range.

\section{PARAMETRIC STUDY}

The accuracy, reliability and effectiveness of the numerical modelling techniques were assured based on satisfactory results obtained from the comparative study - where ultimate strength, load-deflection responses and crack patterns were consistent with those of the experimental outcomes. Therefore, the verified FEM model has been used to carry out a parametric study to investigate the axial failure load of RC walls considering various CFRP layouts, including opening size and location, in this study. 


\subsection{Varying geometric properties}

The size of the numerical wall used in this FE analysis was $3000 \mathrm{~mm}$ by $3000 \mathrm{~mm}$ by $100 \mathrm{~mm}$ corresponding to the height, length and thickness, respectively. A single layer of F60 (6 mm diameter) steel mesh with $100 \mathrm{~mm}$ spacing was placed in the centre of the $\mathrm{RC}$ walls in order to satisfy the minimum requirements of AS3600 [15] for both vertical and horizontal steel ratios. The yield strength of the steel $\left(\mathrm{f}_{\mathrm{y}}\right)$ and compressive strength of concrete were taken as $500 \mathrm{MPa}$ and 50MPa, respectively. The calculation of required CFRP was based on the Swedish Building Administration's handbook on concrete structures BBK04 [30]. The width of the required CFRP $\left(W_{\mathrm{f}}\right)$ and anchorage length of the CFRP layout was calculated based on Eq. 6;

$$
W_{f}=\frac{A_{f}}{t_{f}}
$$

where $A_{f}=\frac{E_{s 2}}{E_{f}}\left(\frac{t_{w}-u-x}{t_{w}-x}\right)^{2} A_{s 2}$ and $x=\frac{a}{0.85}$, in which $a=\frac{A_{s 2} f_{s y}}{0.85 f_{c}^{\prime} L_{w}} \cdot f_{c}^{\prime}$ is concrete compressive strength; $L_{w}$ is concrete wall length; $f_{s y}$ is steel yield stress; $t_{w}$ and $t_{f}$ are the thickness of the wall and CFRP, respectively; $E_{s 2}$ and $E_{f}$ are the modulus of elasticity of steel and CFRP, respectively; $u$ is concrete cover of reinforcement; $A_{s 2}$ and $A_{f}$ are the area of additional steel reinforcement and CFRP cross-sectional area, respectively; $a$ is the depth of the equivalent rectangular stress block. The material properties of CFRP concrete were identical to that used in the comparative study. The loading was applied as a pressure along the top edge of the model to simulate a uniformly distributed load at an eccentricity of $t_{\mathrm{w}} / 6$. A square-shaped opening was considered in this investigation.

Four opening sizes equal to $6 \%, 10 \%, 14 \%$ and $17 \%$ of the wall's area were considered in the modelling. The opening sizes were selected in a way to consider the strengthening of newly constructed RC walls (allowable opening size up to $10 \%$ as determined in AS3600 ${ }^{15}$ ). Larger opening size than that considered in this investigation may need a different strengthening method or requires more CFRP layers, therefore, the opening size was limited to $17 \%$. Also, 
the effects of the opening's location were considered in both horizontal (length) and vertical (height) direction of the wall.

The extent of change in opening location in each direction was constrained by the width of required CFRP in a way that one single CFRP layer was able to be attached to the wall around the opening area. Two main factors were included in the investigation, including CFRP layout and opening configuration. Fig. 9 demonstrates the location and size of the opening in this investigation. A summary of designations for opening sizes, locations and CFRP amount for each layout is presented in Table 3 . In the table, "C" was used to denote walls where an opening was located at the centre of the wall. "L" and " $\mathrm{R}$ " indicated the opening location where the centre of the opening is on the central horizontal axis of the wall and on the left and right side of the central vertical axis of the wall, respectively.

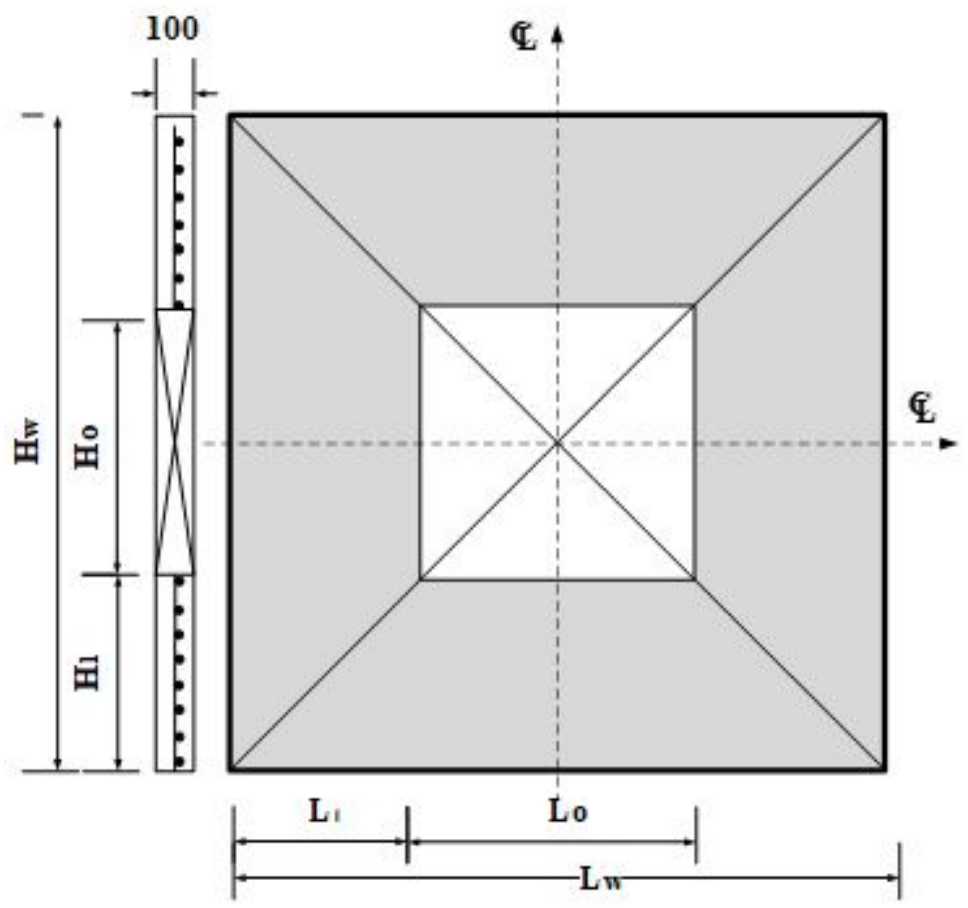

FIGURE 9 Schematic view of RC walls for the parametric study 
TABLE 3 Opening configuration and CFRP usage for the parametric study

$\left(\mathrm{H}_{\mathrm{W}}=\mathrm{L}_{\mathrm{w}}=3000 \mathrm{~mm}, \mathrm{t}_{\mathrm{w}}=100 \mathrm{~mm}\right)$

\begin{tabular}{|c|c|c|c|c|c|c|c|c|}
\hline \multirow{3}{*}{$\begin{array}{l}\text { Opening } \\
\text { designation }\end{array}$} & \multirow{2}{*}{\multicolumn{3}{|c|}{$\begin{array}{l}\text { Opening location } \\
\text { dimension }(\mathrm{mm})\end{array}$}} & \multicolumn{5}{|c|}{ CFRP dimension (mm) } \\
\hline & & & & \multirow{2}{*}{ Width } & \multicolumn{4}{|l|}{ Length } \\
\hline & $\mathrm{L}_{1}$ & $\mathrm{H}_{1}$ & $\mathrm{H}_{\mathrm{o}}\left(=\mathrm{L}_{\mathrm{o}}\right)$ & & $\mathrm{DF}$ & $\mathrm{AF}$ & $\mathrm{CF}$ & WF \\
\hline OW-750-C0 & 1125 & 1125 & \multirow{4}{*}{750} & \multirow{4}{*}{300} & \multirow{4}{*}{$\# 4 . \times 750$} & \multirow{4}{*}{$\begin{array}{l}\# 4 . \times 155 \\
0\end{array}$} & \multirow{4}{*}{$\begin{array}{l}\# 4 . \times 750 \\
\& \\
\# 4 . \times 155 \\
0\end{array}$} & \multirow{4}{*}{$\begin{array}{l}\# 12^{++} . \times 75 \\
0\end{array}$} \\
\hline OW-750-C1 & 1125 & 1325 & & & & & & \\
\hline OW-750-C2 & 1125 & 1525 & & & & & & \\
\hline OW-750-C3 & 1125 & 1725 & & & & & & \\
\hline OW-950-C0 & 1025 & 1025 & \multirow{8}{*}{950} & \multirow{8}{*}{380} & \multirow{8}{*}{$\# 4 . \times 950$} & \multirow{8}{*}{$\begin{array}{l}\# 4 . \times 191 \\
0\end{array}$} & \multirow{8}{*}{$\begin{array}{l}\# 4 . \times 950 \\
\& \\
\# 4 . \times 1910\end{array}$} & \multirow{8}{*}{$\# 12 . \times 950$} \\
\hline OW-950-C1 & 1025 & 1225 & & & & & & \\
\hline OW-950-C2 & 1025 & 1325 & & & & & & \\
\hline OW-950-C3 & 1025 & 1425 & & & & & & \\
\hline OW-950-L0 & 550 & 1025 & & & & & & \\
\hline OW-950-L3 & 550 & 1425 & & & & & & \\
\hline OW-950-R0 & 1500 & 1025 & & & & & & \\
\hline OW-950-R3 & 1500 & 1425 & & & & & & \\
\hline $\mathrm{OW}-1125-\mathrm{C} 0$ & 937.5 & 937.5 & \multirow{4}{*}{1125} & \multirow{4}{*}{465} & \multirow{4}{*}{$\begin{array}{l}\# 4 . \times 112 \\
5\end{array}$} & \multirow{4}{*}{$\begin{array}{l}\# 4 . \times 225 \\
5\end{array}$} & \multirow{4}{*}{$\begin{array}{l}\# 4 . \times 1125 \\
\& \\
\# 4 . \times 2255\end{array}$} & \multirow{4}{*}{$\# 12 . \times 1125$} \\
\hline OW-1125-C1 & 937.5 & 1100 & & & & & & \\
\hline OW-1125-C2 & 937.5 & 1150 & & & & & & \\
\hline OW-1125-C3 & 937.5 & 1200 & & & & & & \\
\hline $\mathrm{OW}-1250-\mathrm{C} 0$ & 875 & 875 & \multirow{4}{*}{1250} & \multirow{4}{*}{505} & \multirow{4}{*}{$\begin{array}{l}\# 4 . \times 125 \\
0\end{array}$} & \multirow{4}{*}{$\begin{array}{l}\# 4 . \times 246 \\
0\end{array}$} & \multirow{4}{*}{$\begin{array}{l}\# 4 . \times 1250 \\
\& \\
\# 4 . \times 2460\end{array}$} & \multirow{4}{*}{$\# 12 . \times 1250$} \\
\hline OW-1250-C1 & 875 & 950 & & & & & & \\
\hline OW-1250-C2 & 875 & 1000 & & & & & & \\
\hline $\mathrm{OW}-1250-\mathrm{C} 3$ & 875 & 1050 & & & & & & \\
\hline
\end{tabular}

+ \#A.: the number of CFRP strips for each layout. For example, \#4. 1550 indicates that four layers of CFRP sheet with a length of $1550 \mathrm{~mm}$ was used.

The ultimate load capacities of CFRP strengthened RC walls under OW action considering various opening configurations with CFRP layouts (DF, AF, CF and WF) were therefore calculated using the FEM analysis and are presented in Table 4. In this Table, $\mathrm{N}_{\mathrm{NF}}$ was the ultimate load for RC walls without CFRP (control) and $\mathrm{N}_{\mathrm{AF}}, \mathrm{N}_{\mathrm{DF}}, \mathrm{N}_{\mathrm{CF}}$ and $\mathrm{N}_{\mathrm{WF}}$ were the ultimate loads of CFRP strengthened RC walls with AF, DF, CF and WF layout.

5.2 Varying opening size. 
The Table 4 parametric study results indicated that, in considering various opening ratios as highlighted in Table 3 (from $6 \%$ to $17 \%$ ), the application of CFRP with the DF layout insignificantly contributed to the ultimate strength of walls under OW action where an approximate 3\% enhancement was observed. This might be attributed to the CFRP layout not being provided in the area where $\mathrm{RC}$ walls experience the most common bending failure. $\mathrm{A}$ similar trend was observed for the WF pattern, whose failure load increased slightly more than that of the DF pattern. This slight increase was attributed to the extra wall area experiencing bending having CFRP applied to assist with the load distribution. The amount of applied CFRP for RC walls with the WF layout was triple that of walls with the DF pattern however, yet both layouts resulted in comparative similar low rates of enhancement in ultimate load.

TABLE 4 Ultimate load comparison for CFRP strengthened RC walls with OW

\begin{tabular}{|c|c|c|c|c|c|c|c|c|c|}
\hline \multirow{2}{*}{$\begin{array}{c}\text { Wall } \\
\text { designation }\end{array}$} & \multicolumn{5}{|c|}{ Ultimate load (kN) } & \multicolumn{4}{|c|}{ Failure load increase (\%) } \\
\hline & $\mathrm{N}_{\mathrm{NF}}^{1}$ & $\mathrm{~N}_{\mathrm{AF}}^{2}$ & $\mathrm{~N}_{\mathrm{DF}}^{3}$ & $\mathrm{~N}_{\mathrm{CF}}^{4}$ & $\mathrm{~N}_{\mathrm{WF}}^{5}$ & $\mathrm{~N}_{\mathrm{AF}} / \mathrm{N}_{\mathrm{NF}}$ & $\mathrm{N}_{\mathrm{DF}} / \mathrm{N}_{\mathrm{NF}}$ & $\mathrm{N}_{\mathrm{CF}} / \mathrm{N}_{\mathrm{NF}}$ & $\begin{array}{l}\mathrm{N}_{\mathrm{WF}} / \\
\mathrm{N}_{\mathrm{NF}}\end{array}$ \\
\hline $\mathrm{OW}-750-\mathrm{C} 0$ & 1826.40 & 2054.40 & 1870.94 & 2087.10 & 1893.00 & 12.48 & 2.44 & 14.27 & 3.65 \\
\hline OW-750-C1 & 1831.80 & 2061.00 & 1872.00 & 2088.00 & 1887.00 & 12.51 & 2.19 & 13.99 & 3.01 \\
\hline $\mathrm{OW}-750-\mathrm{C} 2$ & 1858.20 & 2054.40 & 1889.40 & 2087.10 & 1902.00 & 10.56 & 1.68 & 12.32 & 2.36 \\
\hline OW-750-C3 & 1865.10 & 2054.68 & 1926.74 & 2073.82 & 1935.00 & 10.16 & 3.30 & 11.19 & 3.75 \\
\hline OW-950-C0 & 1644.00 & 1944.00 & 1683.46 & 1978.80 & 1695.00 & 18.25 & 2.40 & 20.36 & 3.10 \\
\hline OW-950-C1 & 1638.00 & 1968.00 & 1682.37 & 1972.50 & 1692.00 & 20.15 & 2.71 & 20.42 & 3.30 \\
\hline OW-950-C2 & 1642.50 & 1968.30 & 1692.00 & 1969.50 & 1701.00 & 19.84 & 3.01 & 19.91 & 3.56 \\
\hline OW-950-C3 & 1653.37 & 1957.94 & 1698.00 & 1991.70 & 1707.00 & 18.42 & 2.70 & 20.46 & 3.24 \\
\hline $\mathrm{OW}-1125-\mathrm{C} 0$ & 1484.70 & 1889.10 & 1518.00 & 1926.30 & 1530.00 & 27.24 & 2.24 & 29.74 & 3.05 \\
\hline OW-1125-C1 & 1476.73 & 1887.00 & 1509.00 & 1923.00 & 1536.00 & 27.78 & 2.19 & 30.22 & 4.01 \\
\hline $\mathrm{OW}-1125-\mathrm{C} 2$ & 1474.95 & 1884.92 & 1508.32 & 1921.20 & 1542.00 & 27.80 & 2.26 & 30.26 & 4.55 \\
\hline OW-1125-C3 & 1479.45 & 1869.00 & 1512.00 & 1929.30 & 1539.00 & 26.33 & 2.20 & 30.41 & 4.03 \\
\hline $\mathrm{OW}-1250-\mathrm{C} 0$ & 1371.47 & 1886.21 & 1398.00 & 1894.50 & 1425.60 & 37.53 & 1.93 & 38.14 & 3.95 \\
\hline OW-1250-C1 & 1364.70 & 1834.20 & 1398.00 & 1877.70 & 1422.00 & 34.40 & 2.44 & 37.59 & 4.20 \\
\hline $\mathrm{OW}-1250-\mathrm{C} 2$ & 1356.74 & 1827.00 & 1389.24 & 1878.90 & 1419.00 & 34.66 & 2.40 & 38.49 & 4.59 \\
\hline OW-1250-C3 & 1356.85 & 1818.30 & 1390.81 & 1875.00 & 1410.00 & 34.01 & 2.50 & 38.19 & 3.92 \\
\hline
\end{tabular}

${ }^{1} \mathrm{~N}_{\mathrm{NF}}$ : ultimate load of RC wall without CFRP; ${ }^{2} \mathrm{~N}_{\mathrm{AF}}$ : ultimate load of CFRP strengthened RC walls with $\mathrm{AF}$ layout; ${ }^{3} \mathrm{~N}_{\mathrm{DF}}$ : ultimate load of CFRP strengthened RC walls with DF layout; ${ }^{4} \mathrm{~N}_{\mathrm{CF}}$ : ultimate load of CFRP strengthened RC walls with $\mathrm{CF}$ layout; ${ }^{5} \mathrm{~N}_{\mathrm{WF}}$ : ultimate load of CFRP strengthened RC walls with WF layout. 
The use of the AF layout in walls under OW action significantly contributed to the ultimate load. The wall ultimate strength with the AF layout was enhanced by around $12 \%$ and $34 \%$ for walls with opening sizes of $6 \%$ and $17 \%$, respectively. It is evident that by increasing the size of the opening and consequently applying additional CFRP, the ultimate strength of the RC walls was linearly enhanced. A similar trend was also observed for the CF patterns. Even though the amount of applied CFRP in the CF pattern was 50\% more than that of the AF layout, only a $3 \%$ enhancement in the ultimate strength of the walls was observed in comparison to walls with the AF layout. Noting that in both of these layouts, CFRP was applied all around the opening where the walls were experiencing bending.

\subsection{Varying Opening location}

As shown in Tables 2 and 3, walls were also designed to investigate the results of a change in opening location in the vertical directions. It was found that changing the location of the opening in the vertical direction (up to $53 \%$ in some cases) did not affect the ultimate strength of RC walls with DF and WF layouts. It was evident that by moving an opening in the vertical direction, the wall panels were experiencing bending through the opening area resulting in similar ultimate strengths with variations, around $1 \%$ observed.

The effects of having an opening to the left or right side of the walls' centre were also investigated and the results are presented in Table5. Based on a case study conducted on the CF layout only, it was observed that having an opening on the left or right side of the centre of the wall negligibly affected (less than $1 \%$ ) the ultimate failure loads of the RC wall panels (Table 5). Similar behaviour was expected from walls with other CFRP layouts; therefore, those results were not presented in this section. In summary, it was evident that the opening size significantly affected ultimate strength; however, the location of the opening had an insignificant effect on the ultimate load for walls under supported top and bottom. 
TABLE 5 The effects of opening location on CFRP strengthened walls with OW

\begin{tabular}{|c|c|c|c|c|}
\hline \multirow{2}{*}{ Wall designation } & \multirow{2}{*}{$\chi$} & \multicolumn{2}{|c|}{ Ultimate load (kN) } & \multirow{2}{*}{$\frac{\mathrm{N}_{\mathrm{CF}}}{\mathrm{N}_{\mathrm{NF}}}$} \\
\hline & & $\mathrm{N}_{\mathrm{NF}}^{1}$ & $\mathrm{~N}_{\mathrm{CF}^{2}}$ & \\
\hline OW-950-C0-L & \multirow{2}{*}{0.243} & 1646 & 1969 & 1.20 \\
\hline OW-950-C3-L & & 1654 & 1969 & 1.19 \\
\hline OW-950-C0 & \multirow{2}{*}{0.317} & 1644 & 1979 & 1.20 \\
\hline OW-950-C3 & & 1653 & 1992 & 1.20 \\
\hline OW-950-C0-R & \multirow{2}{*}{0.39} & 1646 & 1965 & 1.19 \\
\hline OW-950-C3-R & & 1654 & 1993 & 1.20 \\
\hline
\end{tabular}

${ }^{1} \mathrm{~N}_{\mathrm{NF}}$ : the ultimate load of the RC wall without CFRP; ${ }^{2} \mathrm{~N}_{\mathrm{CF}}$ : the ultimate load of CFRP strengthened RC walls with CF layout.

\section{DESIGN CHART FOR CFRP STRENGTHENED WALLS}

Based on the parametric study discussed in Section 5, a design chart is proposed for CFRP strengthened walls. The design chart presents a dimensionless quantity for $\mathrm{N} * \mathrm{~F} / \mathrm{N}_{\mathrm{NF}}$ versus $A_{o} / A$, in which: $N_{N F}$ is the ultimate load of the RC wall without CFRP and $N_{F}$ represents the ultimate load of CFRP strengthened RC walls with various CFRP layouts. The subscript * is replaced by $\mathrm{D}, \mathrm{A}, \mathrm{C}$, and $\mathrm{W}$ for $\mathrm{CFRP}$ layout type of $\mathrm{DF}, \mathrm{AF}, \mathrm{CF}$ and $\mathrm{WF}$, respectively. $\mathrm{A}_{\mathrm{o}}$ and A are the cross-sectional area of the opening $\left(A_{o}=L_{o} t_{w}\right)$ and that of the wall $\left(A=L_{w} t_{w}\right)$, respectively. In the design chart, the equation (Eq.7) for each CFRP strengthening scheme was also provided where a general trend was observed as follows:

$$
\frac{\mathrm{N}_{* \mathrm{~F}}}{\mathrm{~N}_{\mathrm{NF}}}=a\left(\frac{A_{o}}{A}\right)+b
$$

where $a$ is the gradient of the line and $b$ is the $\mathrm{N} *_{\mathrm{F}} / \mathrm{N}_{\mathrm{NF}}$ intercept.

As discussed previously in Section 5.2 and 5.3, the ultimate capacity of OW walls is not significantly affected by the location of the opening. However, varying the opening size and using alternate CFRP layouts considerably affects the ultimate capacity of walls with one-way 
action. Note that the outcome of this investigation is presented in Fig. 10 as an average ultimate load ratio versus the opening ratio of panels. Table 4 presents the detailed information of the ultimate axial capacity of each RC wall that is used in producing Fig. 10.

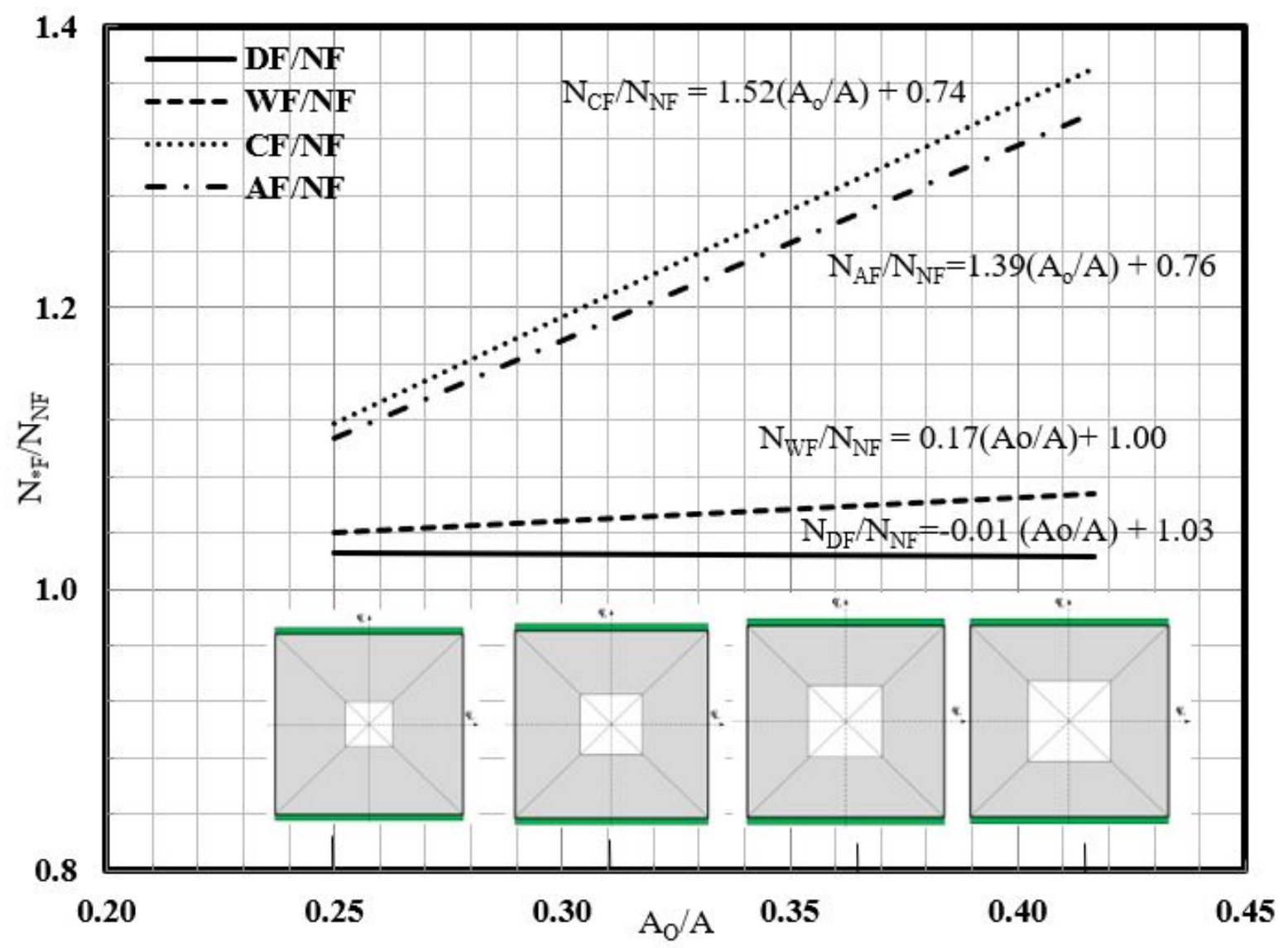

FIGURE 10 Ultimate load ratios versus opening ratios

\subsection{Procedure to use design chart}

The proposed design chart presented in Fig. 10 is based on the principle of numerical prediction for the practical application of CFRP strengthened walls under one-way action. In this section, a step-by-step design method for CFRP strengthened walls is introduced as an illustrative design procedure. A comparative study is then carried out to verify the accuracy and effectiveness of the proposed method. The design process is carried out as follows:

Step 1: Identify geometric properties including the dimension of the wall $\left(\mathrm{H}_{\mathrm{w}}, \mathrm{L}_{\mathrm{w}}, \mathrm{t}_{\mathrm{w}}\right)$ including opening size $\left(\mathrm{H}_{\mathrm{o}}, \mathrm{L}_{\mathrm{o}}\right)$ and location; 
Step 2: Identify material properties such as concrete strength $\left(\mathrm{f}_{\mathrm{c}}\right)$; concrete density, reinforcement yield stress $\left(f_{y}\right)$, the reinforcement ratios vertically $\left(\rho_{v}\right)$ and horizontally $\left(\rho_{h}\right)$ as well as the thickness, density, tensile modulus and tensile strength of CFRP.

Step 3: Determine the type of CFRP layout such as DF, WF, AF or CF, then the dimension of the CFRP layer based on Eq. 6 .

Step 4: Define $A_{o} / A$ and $\chi$. Based on the size of the opening and its location, as well as the support condition, an appropriate chart should be chosen from Fig. 10.

Step 5: Calculate the ultimate load of RC walls with an opening using an existing formula proposed by previous researchers $[7,8,11,18]$ or standards $[14,15]$.

Step 6: Calculate the ultimate load of CFRP strengthened RC walls. Based on the ratio of $A_{o} / A$ or $\chi$ as well as the desired CFRP layout, the ratio of ultimate load of CFRP strengthened walls to that of without CFRP $\left(\mathrm{N} * \mathrm{~F} / \mathrm{N}_{\mathrm{NF}}\right)$ can be easily achieved using the proposed design chart. Having the ratio $\left(\mathrm{N} *_{\mathrm{F}} / \mathrm{N}_{\mathrm{NF}}\right)$ from the chart and also the ultimate load for the wall without CFRP (calculated in Step 5), the ultimate load of the CFRP strengthened RC walls $(\mathrm{N} * \mathrm{~F})$ can be determined.

In the following section, a typical case study is presented to the illustrative purpose and as a guide for using the design chart.

\section{CASE STUDY}

The purpose of these examples was to illustrate and apply the currently proposed design chart (given in Fig. 10) for a real project. It was assumed that the wall size and properties of the RC wall panel were as follows:

$\mathrm{H}_{\mathrm{w}}=3000 \mathrm{~mm}, \mathrm{~L}_{\mathrm{w}}=3000 \mathrm{~mm}, \mathrm{t}_{\mathrm{w}}=100 \mathrm{~mm}, \mathrm{f}_{\mathrm{c}}^{\prime}=50 \mathrm{MPa}, \mathrm{f}_{\mathrm{y}}=450 \mathrm{MPa}, \mathrm{e}=\mathrm{t}_{\mathrm{w}} / 6$ and the opening size was $\mathrm{H}_{\mathrm{o}}=950 \mathrm{~mm}, \mathrm{~L}_{\mathrm{o}}=950 \mathrm{~mm}(10 \%$ opening) (see Fig. 11). 


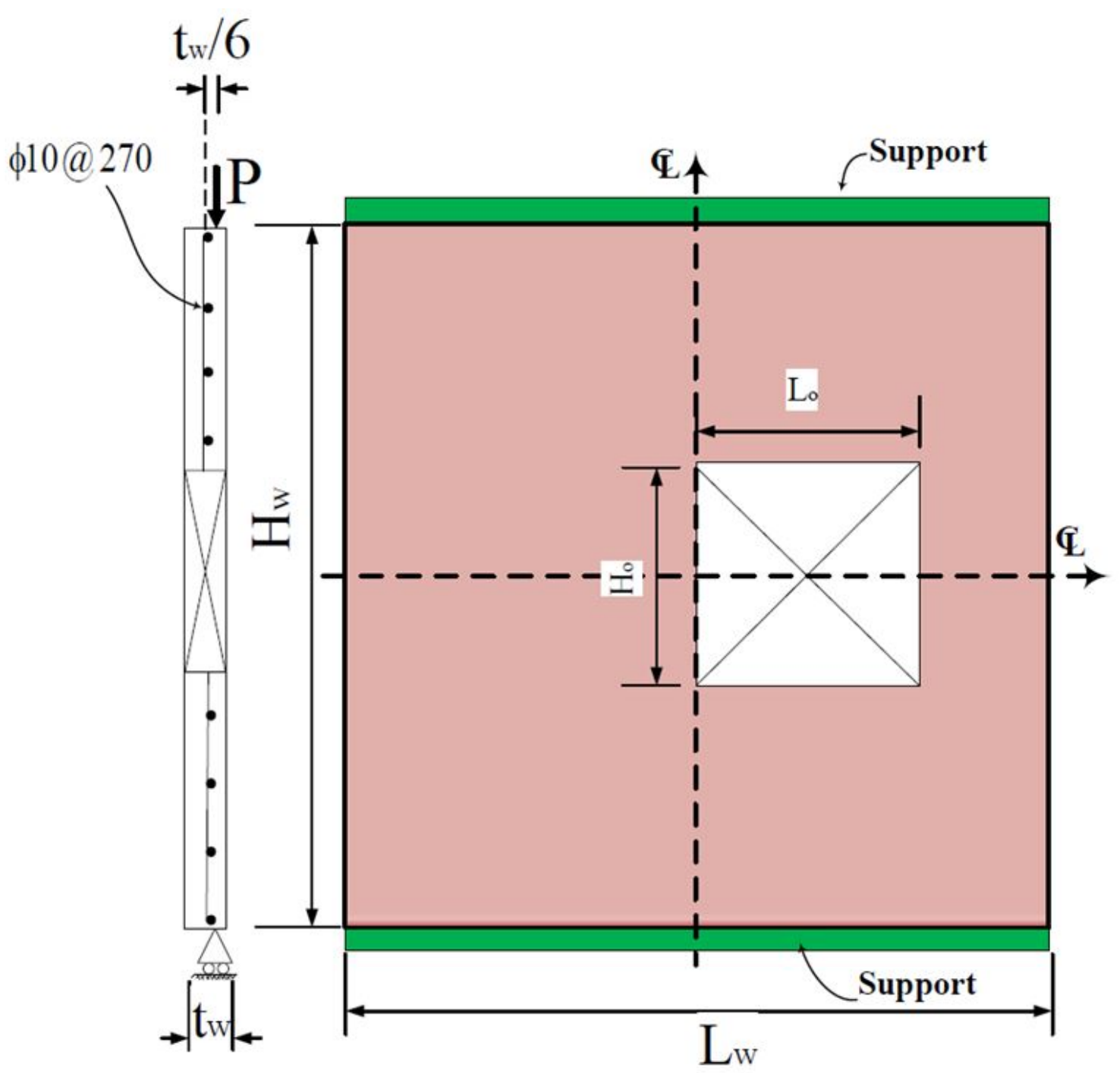

(a) Side view

(b) Front view

FIGURE 11 Schematic view of the wall

The step-by-step procedure for the strengthening of RC walls was as follows:

Step 1: Identify the geometric properties

The height $\left(\mathrm{H}_{\mathrm{w}}\right)$ and length $\left(\mathrm{L}_{\mathrm{w}}\right)$ of the wall are equal to $3000 \mathrm{~mm}$ with a thickness $\left(\mathrm{t}_{\mathrm{w}}\right)$ of $100 \mathrm{~mm}$. The height $\left(\mathrm{H}_{\mathrm{o}}\right)$ and length $\left(\mathrm{L}_{\mathrm{o}}\right)$ of the opening are equal to $950 \mathrm{~mm}$.

Step 2: Identify material properties

The concrete compressive strength $\left(\mathrm{f}_{\mathrm{c}}\right)$ is $50 \mathrm{MPa}$ and yield strength of reinforcement $\left(\mathrm{f}_{\mathrm{y}}\right)$ is $450 \mathrm{MPa}$. The reinforcement ratios are identical in both the vertical $\left(\rho_{\mathrm{v}}\right)$ and horizontal $\left(\rho_{\mathrm{h}}\right)$ direction and equal to 0.0029 which conform to the AS3600 [15] requirement. The CFRP 
material properties in this example are the same as the material properties presented in Lima et al. [17]

Step 3: Determine the CFRP layout

Using Eq. 6, the width and length of each CFRP layout was calculated and presented in Table 6.

Step 4: define $A_{o} / A$ and $\chi$ using the proposed formula by Saheb and Desayi [18].

$$
\begin{aligned}
& \frac{A_{o}}{A}=\left(\frac{950 \times 100}{3000 \times 100}\right)=0.317, \eta_{\mathrm{o}}=1975 \mathrm{~mm} \\
& \bar{\eta}=\left(\frac{\frac{1}{2} \mathrm{t}_{\mathrm{W}} \mathrm{L}_{\mathrm{w}}^{2}-\mathrm{t}_{\mathrm{w}} \mathrm{L}_{\mathrm{o}} \eta_{\mathrm{o}}}{\mathrm{L}_{\mathrm{w}} \mathrm{t}_{\mathrm{w}}-\mathrm{L}_{\mathrm{o}} \mathrm{t}_{\mathrm{w}}}\right)=\left(\frac{\frac{1}{2} \times 100 \times 3000^{2}-100 \times 950 \times 1975}{3000 \times 100-950 \times 100}\right)=1279.88 \mathrm{~mm} \\
& \eta=\left(\frac{\mathrm{L}}{2}-\bar{\eta}\right)=\left(\frac{3000}{2}-1279.88\right)=220.12 \mathrm{~mm} \text { and } \chi=\left(\frac{\mathrm{Ao}}{\mathrm{A}}+\frac{\eta}{\mathrm{L}}\right)=\left(\frac{950 \times 100}{3000 \times 100}+\frac{220.12}{3000}\right)=0.39
\end{aligned}
$$

\begin{tabular}{|c|c|c|c|c|c|c|c|c|}
\hline \multicolumn{5}{|c|}{ CFRP dimension (mm) } & \multicolumn{4}{|c|}{$\begin{array}{l}\text { The total amount of } \\
\text { CFRP usage }\left(\times 10^{6} \mathrm{~mm}^{2}\right)\end{array}$} \\
\hline \multirow{2}{*}{ Width } & \multicolumn{4}{|c|}{ Length } & \multirow{2}{*}{ DF } & \multirow{2}{*}{$\mathrm{AF}$} & \multirow{2}{*}{$\mathrm{CF}$} & \multirow{2}{*}{ WF } \\
\hline & DF & $\mathrm{AF}$ & $\mathrm{CF}$ & WF & & & & \\
\hline 380 & $\# 4 . \times 950$ & $\# 4 . \times 1910$ & $\begin{array}{c}\# 4 . \times 950 \\
\& \\
\# 4 . \times 1910\end{array}$ & $\# 12 . \times 950$ & 1.44 & 2.90 & 4.35 & 4.33 \\
\hline
\end{tabular}

TABLE 6 The amount of required CFRP for various layouts

Step 5: Calculate the ultimate load of the RC walls with openings

Firstly, the ultimate load of the corresponding solid wall should be calculated. In this section, the proposed formula by Doh and Fragomeni ${ }^{7}$ was used.

$\mathrm{e}=\mathrm{t}_{\mathrm{w}} / 6=100 / 6=16.667 \mathrm{~mm}$

For $\mathrm{H}_{\mathrm{w}} / \mathrm{t}_{\mathrm{w}} \geq 27 ; \beta=\frac{18}{\left(\frac{\mathrm{H}_{\mathrm{w}}}{\mathrm{t}_{\mathrm{w}}}\right)^{0.88}}=0.90241$ and $\mathrm{H}_{\mathrm{we}}=\beta \mathrm{H}=0.90241 \times 3000=2707.24 \mathrm{~mm}$ 


$$
\begin{aligned}
& \mathrm{e}_{\mathrm{a}}=\mathrm{H}_{\mathrm{we}}^{2} / 2500 \mathrm{t}_{\mathrm{w}}=(2707.24)^{2} /(2500 \times 100)=29.3166 \mathrm{~mm} \\
& \phi \mathrm{N}_{\mathrm{u}}=\phi 2.0\left(\mathrm{f}_{\mathrm{c}}^{\prime}\right)^{0.7}\left(\mathrm{t}_{\mathrm{w}}-1.2 \mathrm{e}-2 \mathrm{e}_{\mathrm{a}}\right)=2 \times(50)^{0.7}(100-1.2 \times 16.667-2 \times 29.3166) \\
& =660.765 \mathrm{kN} / \mathrm{m} \\
& \mathrm{N}_{\mathrm{u}}=660.765 \times 3=1982.3 \mathrm{kN}
\end{aligned}
$$

In the next step, the proposed formula by Doh and Fragomeni [8] was used to determine the ultimate load of RC walls with openings under OW action.

$$
\mathrm{N}_{\mathrm{NF}}=\left(\mathrm{k}_{1}-\mathrm{k}_{2} \cdot \chi\right) \mathrm{N}_{\mathrm{u}}=(1.175-1.188 \times 0.39) \times 1982.3=1410.7 \mathrm{kN}
$$

Step 6: Calculate the ultimate load of CFRP strengthened RC walls

In this stage, the type of CFRP layout should be defined first. Then, based on the value of $\mathrm{A}_{\mathrm{o}} / \mathrm{A}$, the ratio of $\mathrm{N} *_{\mathrm{F}} / \mathrm{N}_{\mathrm{NF}}$ can be found from the vertical axis of Fig. 10 , or by using the provided equations in the design chart. The ultimate load of RC walls without CFRP was calculated in step 5, which was equal to $\mathrm{N}_{\mathrm{NF}}$, therefore the ultimate load of the CFRP strengthened RC walls can be calculated. For various CFRP layouts the calculated value is in Table 7.

TABLE 7 Predicted ultimate load of CFRP strengthened RC walls with OW (AO/A=0.317)

\begin{tabular}{cccc}
\hline $\begin{array}{c}\text { Type of CFRP } \\
\text { layout }\end{array}$ & $\begin{array}{c}\text { The proposed ratio from } \\
\text { chart } \mathrm{N}_{*} / \mathrm{N}_{\mathrm{NF}}\end{array}$ & $\begin{array}{c}\mathrm{N}_{\mathrm{NF}}{ }^{1} \\
(\mathrm{kN})\end{array}$ & $\begin{array}{c}\mathrm{N}^{2}{ }_{\mathrm{F}}^{2} \\
(\mathrm{kN})\end{array}$ \\
\hline $\mathrm{NF}$ & - & 1410.70 & - \\
$\mathrm{DF}$ & $-0.01 \times 0.317+1.03=1.03$ & - & 1453.02 \\
$\mathrm{AF}$ & $1.39 \times 0.317+0.76=1.20$ & - & 1692.84 \\
$\mathrm{CF}$ & $1.52 \times 0.317+0.74=1.22$ & - & 1721.05 \\
$\mathrm{WF}$ & $0.17 \times 0.317+1.03=1.08$ & - & 1523.55 \\
\hline
\end{tabular}

${ }^{1} \mathrm{~N}_{\mathrm{NF}}$ : ultimate load of RC walls without CFRP; ${ }^{2} \mathrm{~N}_{*}$ : ultimate load of CFRP strengthened RC walls with various CFRP layouts 


\section{LIMITATION AND VERIFICATION}

\subsection{Limitation}

Although a comparative study of predicted to test results indicates that the design formula is accurate and reliable, assumptions involved in the development of the charts/formula are as follows:

a) The area of reinforcement required is not calculated from the applied loads but via the AS3600 [15] o satisfy minimum structural and durability requirements. Thus the wall shall have a minimum reinforcement $\rho_{\mathrm{v}} \geq 0.0015$ and $\rho_{\mathrm{h}} \geq 0.0025$ in the vertical and horizontal directions, respectively.

b) The widths of CFRP layouts were calculated from Eqs. 1-4 presented in Lima et al. [17] which are based on the Swedish Building Administration's handbook on concrete structures (BBK04 [30]).

c) The opening ratio was limited to between $6 \%$ and $17 \%$ and the opening was located away from the edges of the RC walls.

d) This design method is proposed considering a single opening in walls, therefore, for $\mathrm{RC}$ walls with multiple openings more investigation is required prior to using design chart.

e) The proposed design chart is only applicable to OW walls.

f) Further Investigation should be completed to consider various slenderness ratios, aspect ratios, and support conditions.

\subsection{Verification of the proposed method}

The verification of the proposed design chart was completed by comparing the ultimate load of the RC walls strengthened with CFRP layouts reported from previous experiments [16-17]. The mean of the ratio (predicted/test) and its coefficient of variation were calculated and are 
presented (Table 8). In this table, WO1b-WO4b and WO1C-WO4C were the walls strengthened by AF and DF layouts considering various opening sizes, respectively [16]. The proposed formulae by Doh and Fragomeni [7-8] were used to predict the ultimate strength of the RC panels both with $\left(\mathrm{N}_{\mathrm{u}}\right)$ and without openings $\left(\mathrm{N}_{\mathrm{NF}}\right)$. From the comparison and investigation between the existing formula and proposed design method, a number of conclusions are drawn:

a) The proposed design method can conservatively predict the ultimate load of CFRP strengthened RC walls with various CFRP layouts and opening configurations;

b) The proposed charts give a safe estimate of failure load for all panels with a mean predicted/test ratio of 0.75 and a standard deviation of 0.17 . Even though Eq. 1 has a marginally higher mean value (0.82), the standard deviation is slightly higher $(0.19)$. This suggests that the proposed design chart safely predict the ultimate load and is also more reliable due to the lower standard deviation. The accuracy difference between the proposed design chart and existing formula (Eq. 1) can be related to a different outcome for DF and AF layouts in two different experiments [16-17] as discussed in Introduction and Section 4.

c) The proposed design method can reasonably predict the ultimate load of RC walls strengthened with the various CFRP layouts, including DF, AF, CF and WF. However, Eq. 1 is only applicable for only DF and AF layouts;

d) The application of Eq. 1 to determine the ultimate load of RC walls resulted in an unsafe prediction for walls strengthened with the DF layout as the predicted/test ratio is greater than 1. This suggests that Eq. 1 is limited in application. In contrast, the proposed design method is acceptable as all the experimental test results fall well above the predicted design load;

e) The proposed design method is able to predict the ultimate load of CFRP strengthened RC walls for of the range of normal concrete strengths ( $\mathrm{f}_{\mathrm{c}}=15 \mathrm{MPa}$ to $65 \mathrm{MPa}$ ); slenderness 
ratios $\left(\mathrm{H}_{\mathrm{w}} / \mathrm{t}_{\mathrm{w}}=20\right.$ and 30$)$ and aspect ratios $\left(\mathrm{H}_{\mathrm{w}} / \mathrm{L}_{\mathrm{w}}=1\right.$ and 2$)$. It could also reasonably predict the ultimate load of walls with larger opening sizes (up to 30\%). This suggests that the proposed design method is not only applicable for a newly constructed wall, in which the opening ratio is limited to $10 \%$ (AS 3600-[15]) and good concrete quality is expected, but also it can be applied to the rehabilitation and retrofitting of panels in existing buildings. 
TABLE 8 Comparison of ultimate load using the proposed design method

\begin{tabular}{|c|c|c|c|c|c|c|c|c|c|}
\hline & \multirow{2}{*}{$\begin{array}{l}\text { Wall } \\
\text { designation }\end{array}$} & \multirow{2}{*}{$\begin{array}{c}\chi \text { or } \\
\mathrm{Ao} / \mathrm{A}\end{array}$} & \multirow{2}{*}{$\begin{array}{c}\mathrm{f}_{\mathrm{c}}^{\prime} \\
(\mathrm{MPa})\end{array}$} & \multirow{2}{*}{$\begin{array}{c}\mathrm{t}_{\mathrm{w}} \\
(\mathrm{mm})\end{array}$} & \multicolumn{3}{|c|}{ Ultimate failure load $(\mathrm{kN})$} & \multirow{2}{*}{$\frac{\text { Eq. } 1}{\operatorname{Exp}}$} & \multirow{2}{*}{$\frac{\text { Proposed }}{\text { Exp }}$} \\
\hline & & & & & $\operatorname{Exp}^{1}$ & Eq. $1^{2}$ & Proposed $^{3}$ & & \\
\hline \multirow{7}{*}{ 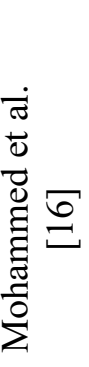 } & WO1b-AF & 0.238 & 15.0 & 40.0 & 149.90 & 143.43 & 99.38 & 0.96 & 0.66 \\
\hline & WO2b-AF & 0.338 & 17.1 & 40.0 & 139.10 & 118.01 & 106.50 & 0.85 & 0.77 \\
\hline & WO3b-AF & 0.463 & 18.2 & 40.0 & 108.00 & 80.43 & 102.82 & 0.74 & 0.95 \\
\hline & WO4b-AF & 0.575 & 15.1 & 40.0 & 82.00 & 43.29 & 78.56 & 0.53 & 0.96 \\
\hline & WO1C-DF & 0.238 & 14.7 & 40.0 & 175.40 & 166.76 & 92.38 & 0.95 & 0.53 \\
\hline & WO2C-DF & 0.338 & 15.6 & 40.0 & 157.20 & 129.57 & 83.46 & 0.82 & 0.53 \\
\hline & WO3C-DF & 0.463 & 16.4 & 40.0 & 138.50 & 85.89 & 69.50 & 0.62 & 0.50 \\
\hline \multirow{7}{*}{ 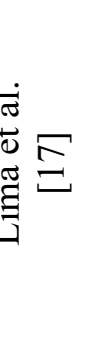 } & WO4C-DF & 0.575 & 17.0 & 40.0 & 84.80 & 53.35 & 56.15 & 0.63 & 0.66 \\
\hline & OW-DF & 0.375 & 55.1 & 40.0 & 309.00 & 360.19 & 253.41 & 1.17 & 0.82 \\
\hline & OW-AF & 0.375 & 54.7 & 40.0 & 335.70 & 315.96 & 315.61 & 0.94 & 0.94 \\
\hline & OW-WF & 0.375 & 62.6 & 43.5 & 559.00 & - & 486.93 & $\mathrm{~N} / \mathrm{A}$ & 0.87 \\
\hline & $\mathrm{OW}-\mathrm{CF}$ & 0.375 & 62.6 & 46.0 & 415.05 & - & 329.41 & N/A & 0.79 \\
\hline & & & & & & & Mean & 0.82 & 0.75 \\
\hline & & & & & & & STDV & 0.19 & 0.17 \\
\hline
\end{tabular}

Exp: experimental; ${ }^{2}$ Eq. 1: proposed equation by Mohammed et al. [16]; ${ }^{3}$ Proposed: current proposed design method

\section{CONCLUSION}

Openings within a RC wall can significantly reduce the ultimate capacity of the wall, therefore strengthening methods are often required to reinstate the original capacity of the wall. In this regard, this paper investigated the behaviour of $\mathrm{RC}$ walls acting in one-way action with an opening strengthened with CFRP. An FE model was established, based on the existing experiments on RC walls with an opening, followed by a comprehensive numerical investigation to consider various factors including CFRP layout, opening size and location. A design chart was proposed based on the obtained output and was validated against existing experimental results. It was evident that the proposed design chart was capable of reasonably predicting the axial load capacity of the RC walls in comparison to the existing formulae. Further investigation is required to investigate the effects of various slenderness ratio, aspect ratio, multiple openings, alternative CFRP layers and support conditions to enhance the proposed design chart. 


\section{REFERENCES}

1. Lima, M.M., Doh, J.H., Hadi, MNS. \& Miller, D. The effects of CFRP orientation on the strengthening of reinforced concrete structures, The Structural Design of Tall and Special Buildings, 2016; 25-15, 759-784.

2. ACI 440. Guide for the design and construction of externally bonded FRP systems for strengthening concrete structures American Concrete Institute.2002.

3. Fib Bullettin 14. Externally bonded FRP reinforcement for RC structures. Federation Internationale du Beton. 2001.

4. JSCE. Recommendations for upgrading of concrete structures with use of continuous fiber sheets. Research Committee on Upgrading of Concrete Structures with Use of Continuous Fiber Sheets, Japanese Society of Civil Engineers. 2000.

5. ISIS. Retrofitting concrete structures with fiber reinforced polymers. Canada. 2001.

6. TR 55. Design guidance for strengthening concrete structures using fibre composite materials. Concrete Society, UK. 2012.

7. Doh, J.-H. \& Fragomeni, S. Evaluation of experimental work on concrete walls in one and two-way action. Australian Journal of Structural Engineering, 2005; 6(1) :37-52.

8. Doh, J.-H. \& Fragomeni, S. Ultimate load formula for reinforced concrete wall panels with openings. Advances in Structural Engineering, 2006; 9: 103-115.

9. Fragomeni, S., Doh, J.-H. \& Lee, D. Behavior of Axially Loaded Concrete Wall Panels with Openings: An Experimental Study. Advances in Structural Engineering, 2012;15: $1345-1358$.

10. Popescu, C., Sas, G., Sabău, C. and Blanksvärd, T. Effect of cut-out openings on the axial strength of concrete walls. Journal of Structural Engineering. 2016; 142(11). DOI: 10.1061/32 (ASCE)ST.1943-541X.0001558.

11. Ho, N.M. \& Doh, J.H. Design Assisted by Testing Applied to the Determination of the Design Resistance of RC Walls Restrained on Three Sides. $15^{\text {th }}$ East Asia-Pacific Conference on Structural Engineering and Construction (EASEC-15), 11-13 October, 2017. Xi'an, China. 1371-1378.

12. Ho, N.M. and Doh, J.H. Experimental and numerical investigations of axially loaded RC walls restrained on three sides. The Structural Design of Tall and Special Buildings, 2018. DOI: $10.1002 /$ tal.1459.

13. Ho, N.M. and Doh, J.H. Prediction of ultimate strength of concrete walls restrained on three sides, Structural Concrete, 2019. DOI:10.1002/suco.201800188.

14. ACI 318. Building code requirements for reinforced concrete, American Concrete Institute, Detroit, Michigan. 2014. 
15. AS3600. Concrete Structures. Standards Association of Australia, 2018.

16. Mohammed, B. S., Ean, L. \& Malek, M. 2013. One way RC wall panels with openings strengthened with CFRP. Construction and Building Materials, 40, 575-583.

17. Lima, M.M., Doh, J.H., and Hadi, MNS. Experimental Study on RC Walls with Opening Strengthened by Externally Bonded CFRP, Journal of Composites for construction, 2019. DOI: 10.1061/(ASCE)CC.1943-5614.0000930

18. Saheb, S. M. \& Desayi, P. 1990. Ultimate strength of RC wall panels with openings. Journal of Structural Engineering, 116, 1565-1577.

19. Popescu, C., G. Sas, T. Blanksvärd, and B. Täljsten. 2016a. "Concrete walls with cutout openings strengthened by FRP confinement.” J. Compos. Constr. 21 (3): 04016106. https://doi.org/10.1061/(ASCE)CC.1943 -5614.0000759.

20. Popsecu 2017: Cosmin Popescu, Jacob W. Schmidt, Per Goltermann, Gabriel Sas, Assessment of RC walls with cut-out openings strengthened by FRP composites using a rigid-plastic approach, Engineering Structures, Volume 150, 2017, Pages 585-598, ISSN 0141-0296, https://doi.org/10.1016/j.engstruct.2017.07.069. (http://www.sciencedirect.com/science/article/pii/S0141029617324264)

21. Numerical study on the low-velocity impact response of ultra-high-performance fiber reinforced concrete beams; S Nasrin, A Ibrahim Structures, 2019 - Elsevier; Volume 20, August 2019, Pages 570-580; https://doi.org/10.1016/j.istruc.2019.06.011

22. Ammar N. Hanoon, M.S. Jaafar, Farzad Hejazi, Farah N.A. Abdul Aziz, "Strut-and-tie model for externally bonded CFRP-strengthened reinforced concrete deep beams based on particle swarm optimization algorithm: CFRP debonding and rupture, Construction and Building Materials,Volume 147,2017, Pages 428-447, ISSN 0950-0618, https://doi.org/10.1016/j.conbuildmat.2017.04.094.

23. Bassam Q. Abdulrahman, Zhangjian Wu, Lee S. Cunningham, Experimental and numerical investigation into strengthening flat slabs at corner columns with externally bonded CFRP, Construction and Building Materials, Volume 139,2017, Pages 132-147, ISSN 0950-0618, https://doi.org/10.1016/j.conbuildmat.2017.02.056.

24. Garyfalia G. Triantafyllou, Theodoros C. Rousakis, Athanasios I. Karabinis, Corroded $\mathrm{RC}$ beams patch repaired and strengthened in flexure with fiber-reinforced polymer laminates, Composites Part B: Engineering, Volume 112, 2017, Pages 125-136, ISSN 1359-8368, https://doi.org/10.1016/j.compositesb.2016.12.032.

25. Hsu, L. \& Hsu, C.-T. Complete stress - strain behaviour of high-strength concrete under compression. Magazine of Concrete Research, 1994; 46, 301-312. 
26. CEB-FIP . 1990. Model Code FIB-Féd. Int. du Béton.

27. Hibbitt, H., Karlsson, B. \& Sorensen, P. 2011. Abaqus Analysis Users Manual Version 6.10 .

28. Guo, Z., Cao, S., Sun, W. \& Lin, X. Experimental study on bond stress-slip behaviour between FRP sheets and concrete. FRP in construction, proceedings of the international symposium on bond behaviour of FRP in structures, 2005. 77-84.

29. Lu, X., Teng, J., Ye, L. \& Jiang, J. Bond-slip models for FRP sheets/plates bonded to concrete. Engineering structures, 2005; 27, 920-937.

30. BBK. Boverkets Handbok om Betongkonstruktioner, Sweden. (The Swedish Building Administration's Handbook on Concrete Structures): The Swedish Building Administration, Division of Buildings 2004. 